\title{
Future climate impacts of direct radiative forcing of anthropogenic aerosols, tropospheric ozone, and long- lived greenhouse gases
}

\author{
Wei-Ting Chen, ${ }^{1}$ Hong Liao, ${ }^{2}$ and John H. Seinfeld ${ }^{3}$ \\ Received 18 September 2006; revised 26 April 2007; accepted 11 May 2007; published 26 July 2007.
}

[1] Long-lived greenhouse gases (GHGs) are the most important driver of climate change over the next century. Aerosols and tropospheric ozone $\left(\mathrm{O}_{3}\right)$ are expected to induce significant perturbations to the GHG-forced climate. To distinguish the equilibrium climate responses to changes in direct radiative forcing of anthropogenic aerosols, tropospheric ozone, and GHG between present day and year 2100, four 80-year equilibrium climates are simulated using a unified tropospheric chemistry-aerosol model within the Goddard Institute for Space Studies (GISS) general circulation model (GCM) II'. Concentrations of sulfate, nitrate, primary organic (POA) carbon, secondary organic (SOA) carbon, black carbon (BC) aerosols, and tropospheric ozone for present day and year 2100 are obtained a priori by coupled chemistry-aerosol GCM simulations, with emissions of aerosols, ozone, and precursors based on the Intergovernmental Panel on Climate Change (IPCC) Special Report on Emissions Scenario (SRES) A2. Changing anthropogenic aerosols, tropospheric ozone, and GHG from present day to year 2100 is predicted to perturb the global annual mean radiative forcing by +0.18 (considering aerosol direct effects only), +0.65 , and $+6.54 \mathrm{~W} \mathrm{~m}^{-2}$ at the tropopause, and to induce an equilibrium global annual mean surface temperature change of $+0.14,+0.32$, and $+5.31 \mathrm{~K}$, respectively, with the largest temperature response occurring at northern high latitudes. Anthropogenic aerosols, through their direct effect, are predicted to alter the Hadley circulation owing to an increasing interhemispheric temperature gradient, leading to changes in tropical precipitation. When changes in both aerosols and tropospheric ozone are considered, the predicted patterns of change in global circulation and the hydrological cycle are similar to those induced by aerosols alone. GHG-induced climate changes, such as amplified warming over high latitudes, weakened Hadley circulation, and increasing precipitation over the Tropics and high latitudes, are consistent with predictions of a number of previous GCM studies. Finally, direct radiative forcing of anthropogenic aerosols is predicted to induce strong regional cooling over East and South Asia. Wintertime rainfall over southeastern China and the Indian subcontinent is predicted to decrease because of the increased atmospheric stability and decreased surface evaporation, while the geographic distribution of precipitation is also predicted to be altered as a result of aerosol-induced changes in wind flow.

Citation: Chen, W.-T., H. Liao, and J. H. Seinfeld (2007), Future climate impacts of direct radiative forcing of anthropogenic aerosols, tropospheric ozone, and long-lived greenhouse gases, J. Geophys. Res., 112, D14209, doi:10.1029/2006JD008051.

\section{Introduction}

[2] Growth in well-mixed, long-lived greenhouse gas (GHG, including $\mathrm{CO}_{2}, \mathrm{CH}_{4}, \mathrm{~N}_{2} \mathrm{O}$, and halocarbons) levels in the atmosphere is the dominant contributor to future climate change [Intergovernmental Panel on Climate Change (IPCC), 2001]. Against GHG-dominated climate change, radiative forcing from changing aerosols and tropospheric ozone $\left(\mathrm{O}_{3}\right)$ has the potential to modify GHG-induced climate effects, especially regionally. Moreover, ozone and aerosols interact tightly through tropospheric chemical processes, which themselves will be affected by future climate change [Liao and Seinfeld, 2005; Liao et al., 2006]. An important issue, and that to which the present work is

\footnotetext{
${ }^{1}$ Department of Environmental Science and Engineering, California Institute of Technology, Pasadena, California, USA.

${ }^{2}$ State Key Laboratory of Atmospheric Boundary Layer Physics and Atmospheric Chemistry (LAPC), Institute of Atmospheric Physics, Chinese Academy of Sciences, Beijing, China.

${ }^{3}$ Departments of Environmental Science and Engineering and Chemical Engineering, California Institute of Technology, Pasadena, California, USA.

Copyright 2007 by the American Geophysical Union. 0148-0227/07/2006JD008051
} 
directed, concerns the extent to which aerosols and tropospheric ozone will modify future climate change from that predicted to occur solely based on greenhouse gases.

[3] Scattering and absorption of solar radiation by aerosols cool the surface by reducing incident solar radiation on it. Absorbing aerosols, such as black carbon and mineral dust, can heat the atmosphere. Ozone traps outgoing longwave (LW) radiation, thereby warming the atmosphere and surface. These effects alter the energy balance of the earthatmosphere system beyond that arising from GHG alone and induce responses in atmospheric circulations, clouds, and precipitation; for aerosols, see, e.g., Hansen et al. [1997], Boer et al. [2000], Chung et al. [2002], Menon et al. [2002], Jacobson [2004], Wang [2004], Chung and Seinfeld [2005], Ramanathan et al. [2005], Stier et al. [2005], Takemura et al. [2005], Roeckner et al. [2006], and Wang [2007]; and for ozone: Ramaswamy and Bowen [1994], Hansen et al. [1997], Stuber et al. [2001], Mickley et al. [2004], and Shindell et al. [2006].

[4] The goal of the present study is to investigate future climatic impacts from direct aerosol radiative forcing and tropospheric ozone as compared to those predicted to occur from greenhouse gases alone. In this study, we consider only direct radiative effects; indirect radiative effects of aerosols, namely effects of changes in anthropogenic aerosols on cloud processes, are not considered. In that regard, the current study does not present an entire picture of aerosol effects on climate relative to those of greenhouse gases. Nonetheless, it is important to understand the direct aerosol radiative effects on climate so that these may be contrasted in future work with those arising from effects resulting from perturbations in cloud processes. We use the unified Goddard Institute for Space Studies (GISS) general circulation model (GCM) II' with fully coupled simulations of tropospheric chemistry and aerosols [Liao et al., 2003, 2004; Liao and Seinfeld, 2005] to calculate concentrations of aerosols and tropospheric ozone for present day and year 2100, based on the IPCC Special Report on Emissions Scenario (SRES) [Nakićenović et al., 2000] A2 anthropogenic emissions of aerosols/aerosol precursors and ozone precursors. Prediction of both present-day and year 2100 levels of aerosols and ozone is carried out under present-day climate conditions. We then apply the GCM to study climate responses to the changes in ozone and aerosols from present day to 2100 , using saved monthly mean fields of ozone and aerosols. We should note that Liao et al. [2006] have used the same version of the model and shown that $\mathrm{CO}_{2}$-driven climate change can influence the predictions of year 2100 concentrations of ozone and aerosols. The fully coupled impacts of chemistry-aerosol-climate interactions on future climate will be reported subsequently.

[5] A description of model and experimental design is given in section 2 . We examine global climate impacts resulting from aerosols, ozone, and greenhouse gases in section 3. Predicted regional climate changes in southeastern Asia and India are addressed in section 4.

\section{Model Description and Experimental Design} 2.1. The Unified Model

[6] The unified tropospheric chemistry-aerosol model within the GISS GCM II' [Liao et al., 2003, 2004; Liao and Seinfeld, 2005] is used in this work. The GISS GCM II is described by Rind and Lerner [1996] and Rind et al. [1999] and is coupled with a "Q-flux" ocean [Hansen et al., 1984]. The GISS model has been used extensively to probe the climate response to perturbations in greenhouse gas concentrations, solar luminosity, and tropospheric ozone and aerosol burdens [e.g., Grenfell et al., 2001; Rind et al., 2001; Shindell et al., 2001; Menon, 2004; Mickley et al., 2004; Chung and Seinfeld, 2005]. The version used has a horizontal resolution of $4^{\circ}$ latitude by $5^{\circ}$ longitude, with 9 vertical $\sigma$ layers from surface to $10 \mathrm{hPa}$, centered at 959, 894, 786, 634, 468, 321, 201, 103, and $27 \mathrm{hPa}$. The dynamical time step is $1 \mathrm{~h}$. In the Q-flux ocean, monthly horizontal heat transport fluxes are held constant as in Mickley et al. [2004], while changes in the sea surface temperature and sea ice are calculated based on energy exchange with the atmosphere, ocean heat transport, and the ocean mixed layer heat capacity [Hansen et al., 1984; Russell et al., 1985].

[7] Present-day and year 2100 concentrations of sulfate, nitrate, ammonium, primary organic (POA) carbon, secondary organic (SOA) carbon, black carbon (BC) aerosols, and tropospheric ozone are obtained a priori by two separate simulations, each integrating the unified model for 5 years in present-day climate with present-day or year 2100 emissions of aerosols/aerosol precursors and ozone precursors, based on the IPCC SRES A2 emission scenarios (in which heterogeneous world, no emphasis on sustainability, and slow technology development is assumed, and the highest year $2100 \mathrm{CO}_{2}$ and $\mathrm{SO}_{2}$ emissions of all SRES are predicted); these two simulations are similar to those denoted CL2000EM2000 and CL2000EM2100 in Liao et al. [2006] with the difference that heterogeneous reactions on mineral dust and sea salt are neglected here because we focus here on the effects of anthropogenic aerosol components. Hydrolysis of $\mathrm{N}_{2} \mathrm{O}_{5}$ and irreversible absorption of $\mathrm{NO}_{3}, \mathrm{NO}_{2}$, and $\mathrm{HO}_{2}$ on wetted surfaces of $\mathrm{SO}_{4}^{2-}, \mathrm{NO}_{3}^{-}$, $\mathrm{NH}_{4}^{+}$, and $\mathrm{OC}$ aerosols are accounted for. The differences between the calculated present-day and year 2100 aerosol/ $\mathrm{O}_{3}$ concentrations, as discussed later in section 2.3, result entirely from future emission changes, since present-day climate is used in both simulations.

\subsection{Climate Simulations}

[8] To study the climate change resulting from direct radiative forcing of anthropogenic aerosols, tropospheric ozone, and $\mathrm{GHG}$, four equilibrium climate experiments, as summarized in Table 1, were carried out to study the climatic effects of aerosol $/ \mathrm{O}_{3} / \mathrm{GHG}$ changes from present day to year 2100. The GCM is integrated in each case for 80 years, with the first 50 years used as spin-up to reach equilibrium, and the results over the last 30 years of each simulation analyzed and compared. The first simulation, denoted PD, is the baseline, present-day climate with aerosol, $\mathrm{O}_{3}$, and $\mathrm{GHG}$ at year 2000 levels. The second simulation, 21A, uses year 2100 anthropogenic aerosols but present-day tropospheric $\mathrm{O}_{3}$ and $\mathrm{GHG}$ concentrations. The difference between the equilibrium states (the last 30 years in the simulation) of PD and $21 \mathrm{~A}$, referred to as $\triangle \mathrm{AER}$ in subsequent discussion, represents the climatic influence of the change in anthropogenic aerosols from present day to year 2100. In the third experiment, 21AO, both anthropogenic aerosols and tropo- 
Table 1. Summary of Climate Experiments

\begin{tabular}{ccccc}
\hline Experiments & $\begin{array}{c}\text { Anthropogenic Aerosol } \\
\text { Concentration }\end{array}$ & $\begin{array}{c}\text { Tropospheric } \mathrm{O}_{3} \\
\text { Concentration }\end{array}$ & GHG Levels & Perturbation \\
\hline PD & Year 2000 & Year 2000 & Year 2000 & Present-day climate \\
$21 \mathrm{~A}$ & Year 2100 & Year 2000 & Year 2000 & $21 \mathrm{~A}-\mathrm{PD}=\Delta \mathrm{AER}$ \\
$21 \mathrm{AO}$ & Year 2100 & Year 2100 & Year 2000 & $21 \mathrm{AO}-\mathrm{PD}=\Delta \mathrm{AERO}$ \\
$21 \mathrm{G}$ & Year 2000 & Year 2000 & Year 2100 & $21 \mathrm{G}-\mathrm{PD}=\Delta \mathrm{GHG}$ \\
\hline
\end{tabular}

spheric $\mathrm{O}_{3}$ are set at year 2100 levels with GHG levels at present day; the difference between simulations PD and $21 \mathrm{AO}$, referred to as $\triangle \mathrm{AERO}_{3}$, assesses the combined climate effect of changes in both aerosols and tropospheric $\mathrm{O}_{3}$. Lastly, the simulation $21 \mathrm{G}$, which uses present-day aerosol $/ \mathrm{O}_{3}$ but year $2100 \mathrm{GHG}$, is compared to $\mathrm{PD}$ to evaluate the climate effect of GHG changes only ( $\Delta \mathrm{GHG})$. In these equilibrium climate simulations, GHG mixing ratios are taken from the IPCC SRES A2 and grid-by-grid aerosol/ $\mathrm{O}_{3}$ concentrations in present-day (year 2000) or year 2100 levels (see section 2.3) are imported into the model on monthly basis (a 12-month cycle is repeated every simulated year).

[9] We have chosen to simulate equilibrium climate because the focus of this study is on the relative impacts of anthropogenic aerosol direct effect, tropospheric $\mathrm{O}_{3}$, and GHG on climate, and an equilibrium climate is able to clearly delineate this. Note that the equilibrium climate generally results in more pronounced responses than the transient climate [e.g., IPCC, 1995; Kiehl et al., 2006], in which emissions (and forcing) change year by year.

\subsection{Present-Day and Year 2100 Anthropogenic Aerosols, Tropospheric Ozone, and Greenhouse Gases}

[10] Table 2 lists present-day and year 2100 global mixing ratios of long-lived greenhouse gases and global burdens of tropospheric ozone and aerosols. Present-day and year 2100 GHG levels are derived based on the SRES A2 scenarios. Atmospheric $\mathrm{CO}_{2}$ increases from $367 \mathrm{ppmv}$ in present day to $836 \mathrm{ppmv}$ in year 2100 and remains the single most important contributor to GHG radiative forcing in year 2100 .

[11] Figure 1 shows annual and seasonal mean (DJF $=$ December-January-February, JJA = June-July-August) latitude-longitude differences in column burdens between present day and year 2100 for anthropogenic aerosols and $\mathrm{O}_{3}$. All anthropogenic aerosol species are predicted to increase between 2000 and 2100 except for sulfate. Global burdens of POA, nitrate, and $\mathrm{BC}$ are predicted to exhibit substantial growth. East Asia, India, Europe, and the eastern United States are the regions in which the largest increases in aerosol concentrations are predicted. In response to the rising anthropogenic emissions of $\mathrm{O}_{3}$ precursors over 2000-2100, the global $\mathrm{O}_{3}$ burden is predicted to increase by around $200 \mathrm{Tg}$ with the increase higher in the net heat $(\mathrm{NH})$, especially in the vicinity of India, the Near East, southern Africa, and the western United States.

[12] Calculation of aerosol optical properties follows the work of Liao et al. [2004]. We assume that sulfate, nitrate, black carbon, organic carbon (OC; primary organic carbon plus secondary organic carbon) and aerosol water associated with $\mathrm{SO}_{4}^{2-}, \mathrm{NO}_{3}^{-}$, and $\mathrm{OC}$ are internally mixed. Densities for dry sulfate, nitrate, $\mathrm{OC}$, and $\mathrm{BC}$ are assumed to be 1.8 ,
1.7, 1.8 , and $1.0 \mathrm{~g} \mathrm{~cm}^{-3}$, respectively, and the particle density of the internal mixture is computed as the massaveraged density of water and all dry aerosols. A volumeweighted mixing rule is applied to derive the composite, wavelength-dependent refractive indices. The spectral refractive index of dry nitrate is assumed the same as that of dry sulfate [Toon et al., 1976], while the refractive indices for water, OC, and BC are from d'Almeida et al. [1991] (OC as "water-soluble" and $\mathrm{BC}$ as "soot"). A standard gamma size distribution is assumed for the aerosol with a surface area-weighted dry radius $=0.3 \mu \mathrm{m}$ and variance $=0.2$. Mie theory is then applied to determine the optical properties (extinction efficiency, single-scattering albedo, and asymmetry parameter) based on the refractive indices and size distribution.

[13] Figures $2 \mathrm{a}$ and $2 \mathrm{~b}$ show the global distributions of the annual mean instantaneous direct radiative forcing at the tropopause (here defined at the bottom of GCM layer 8) and the surface, respectively, owing to changes in anthropogenic aerosols, tropospheric $\mathrm{O}_{3}$, and GHG between present day and 2100. The instantaneous direct radiative forcing is calculated as the difference in net (solar plus thermal) irradiance at each model layer corresponding to a change in aerosol, $\mathrm{O}_{3}$, or GHG concentration. Aerosols, depending on their optical properties and the albedo of the underlying surface, produce either a positive or a negative forcing at the tropopause, but always result in a negative surface forcing by virtue of reduction of the incident solar radiation at the surface. The overall change of anthropogenic aerosols between present day and year 2100 is predicted to lead to a global annual mean direct forcing of $+0.18 \mathrm{~W} \mathrm{~m}^{-2}$ at the tropopause and $-3.02 \mathrm{~W} \mathrm{~m}^{-2}$ at the surface. Since internal mixing of all anthropogenic aerosol components is assumed, the strong heating at middle to high latitudes in

Table 2. Present-Day (Year 2000) and Year 2100 Annual Mean Global Burdens of Anthropogenic Aerosols, Tropospheric Ozone, and Greenhouse Gas Mixing Ratios Used in This Study ${ }^{\mathrm{a}}$

\begin{tabular}{lcc}
\hline & Year 2000 & Year 2100 \\
\hline Ammonium Sulfate, Tg & 2.83 & 2.70 \\
Ammonium Nitrate, Tg & 0.66 & 2.82 \\
$\mathrm{POA}, \mathrm{Tg}$ & 1.25 & 2.90 \\
$\mathrm{SOA}, \mathrm{Tg}$ & 0.28 & 0.39 \\
$\mathrm{BC}, \mathrm{Tg}$ & 0.23 & 0.53 \\
Tropospheric $\mathrm{O}_{3}, \mathrm{Tg}$ & 327 & 520 \\
$\mathrm{CO}_{2}$, ppmv & 367 & 836 \\
$\mathrm{CH}_{4}$, ppbv & 1760 & 3731 \\
$\mathrm{~N}_{2} \mathrm{O}$, ppbv & 316 & 447 \\
Chlorofluorocarbon (CFC)-11, pptv & 267 & 45 \\
CFC-12, pptv & 535 & 222 \\
\hline
\end{tabular}

${ }^{a}$ Emissions are based on SRES A2 scenario; see Liao et al. [2006] for details of anthropogenic aerosol and tropospheric $\mathrm{O}_{3}$ concentrations. 

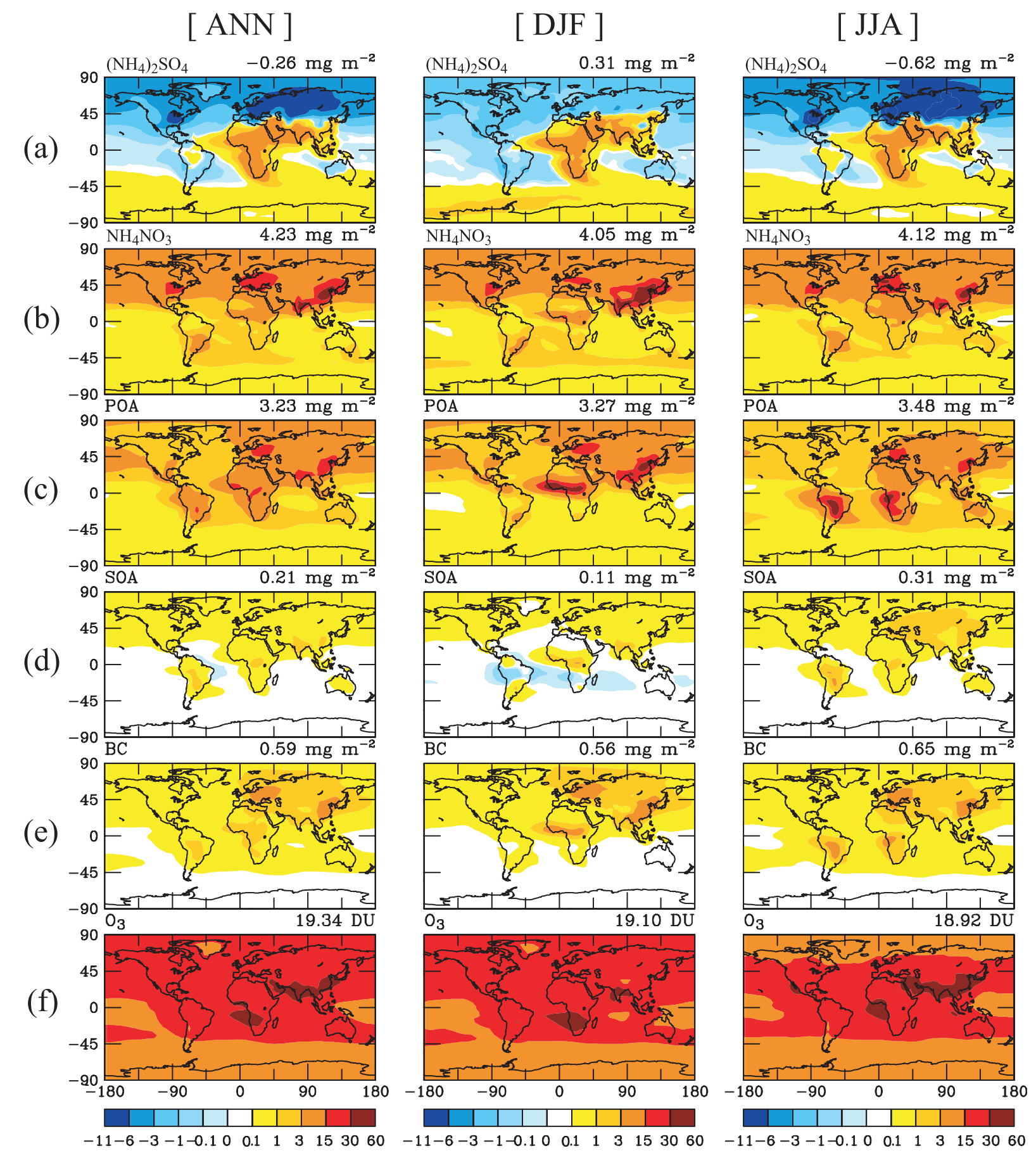

Figure 1. Annual and seasonal differences in column concentrations between present day and year 2100 for anthropogenic aerosols $\left(\mathrm{mg} \mathrm{m}^{-2}\right)$ and tropospheric ozone (Dobson Units): (a) ammonium sulfate, (b) ammonium nitrate, (c) POA, (d) $\mathrm{SOA}$, (e) $\mathrm{BC}$, and (f) $\mathrm{O}_{3}$. ANN = annual mean, DJF = seasonal mean over December-January-February, and JJA = seasonal mean over June-July-August.

the Northern Hemisphere as a result of increasing BC over highly reflective surfaces of snow, sea ice, and desert leads to an overall positive forcing at the tropopause. However, negative aerosol forcing is predicted over eastern China, India, and Western Europe because of the predicted large increase in scattering $\left(\mathrm{NO}_{3}^{-}, \mathrm{POA}\right.$, and $\mathrm{SO}_{4}^{2-}$ in India and southern China) aerosols, although $\mathrm{BC}$ also increases in these regions. The predicted global annual mean forcing attributed to changes in tropospheric ozone from present day to year 2100 is $+0.65 \mathrm{~W} \mathrm{~m}^{-2}$ at the tropopause and $+0.02 \mathrm{~W} \mathrm{~m}^{-2}$ at the surface, with the maximum forcing changes concentrated in the areas of largest increases of tropospheric ozone. Increasing GHG levels from present day to year 2100 according to scenario A2 results in a forcing at the tropopause of $+6.54 \mathrm{~W} \mathrm{~m}^{-2}$ and at surface of $+1.37 \mathrm{~W} \mathrm{~m}^{-2}$. 
[ Anth. Aerosol ]

(a)

(b)
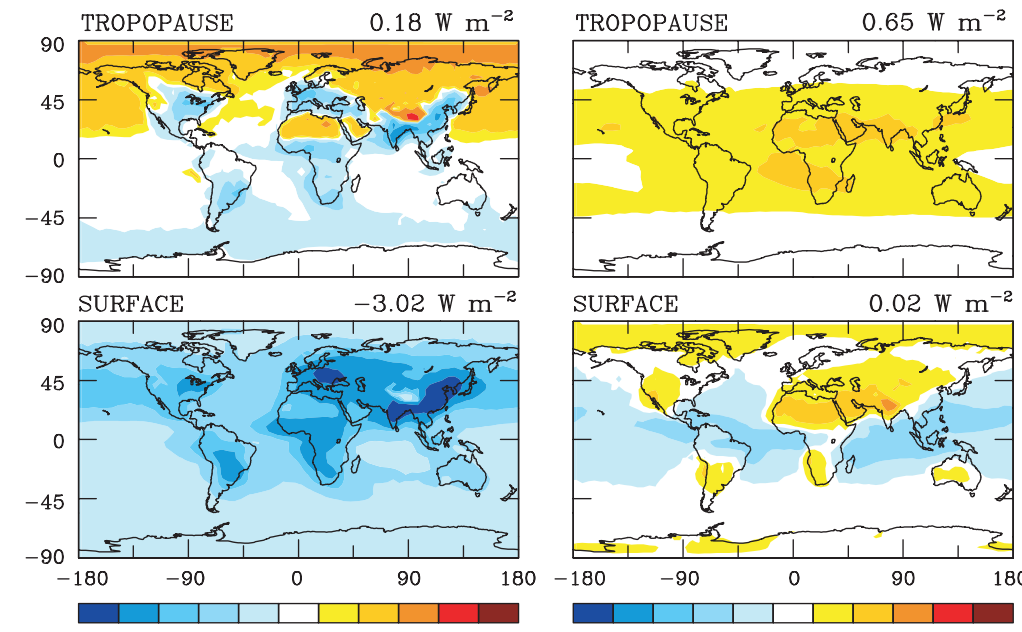

[ GHG ]

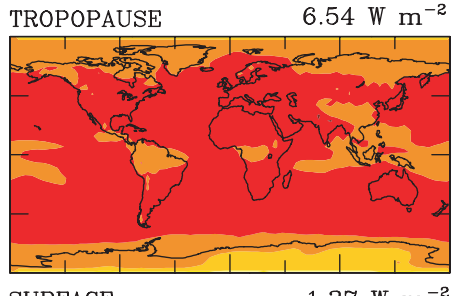

SURFACE $\quad 1.37 \mathrm{~W} \mathrm{~m}^{-2}$

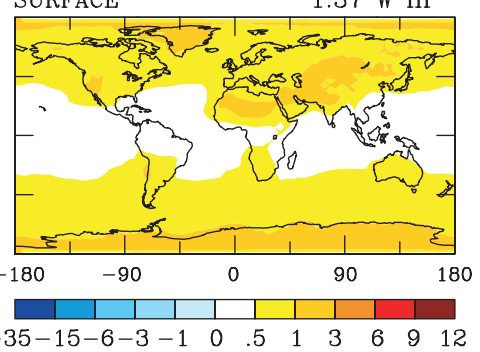

Figure 2. Annual mean change in instantaneous forcing $\left(\mathrm{W} \mathrm{m}^{-2}\right)$ (a) at tropopause and (b) at surface imposed by changes of anthropogenic aerosol (left column), tropospheric ozone (middle column), and greenhouse gases (right column) between present day and year 2100.

[14] Figure 3 shows the vertical distribution of the zonal mean atmospheric forcing, calculated by differencing the instantaneous forcing between top and bottom of each layer, imposed by changes in anthropogenic aerosols, tropospheric ozone, and GHG between present day and year 2100 . The enhanced shortwave (SW) absorption by internally mixed,
BC-containing aerosols is predicted to lead to positive atmospheric forcing immediately above the surface. The positive atmospheric forcing is most pronounced in $\mathrm{NH}$ where the aerosol concentration increase is largest. In DJF, the positive forcing peaks between $0^{\circ}$ and $45^{\circ} \mathrm{N}$, associated with the large increase in wintertime fossil fuel emissions in

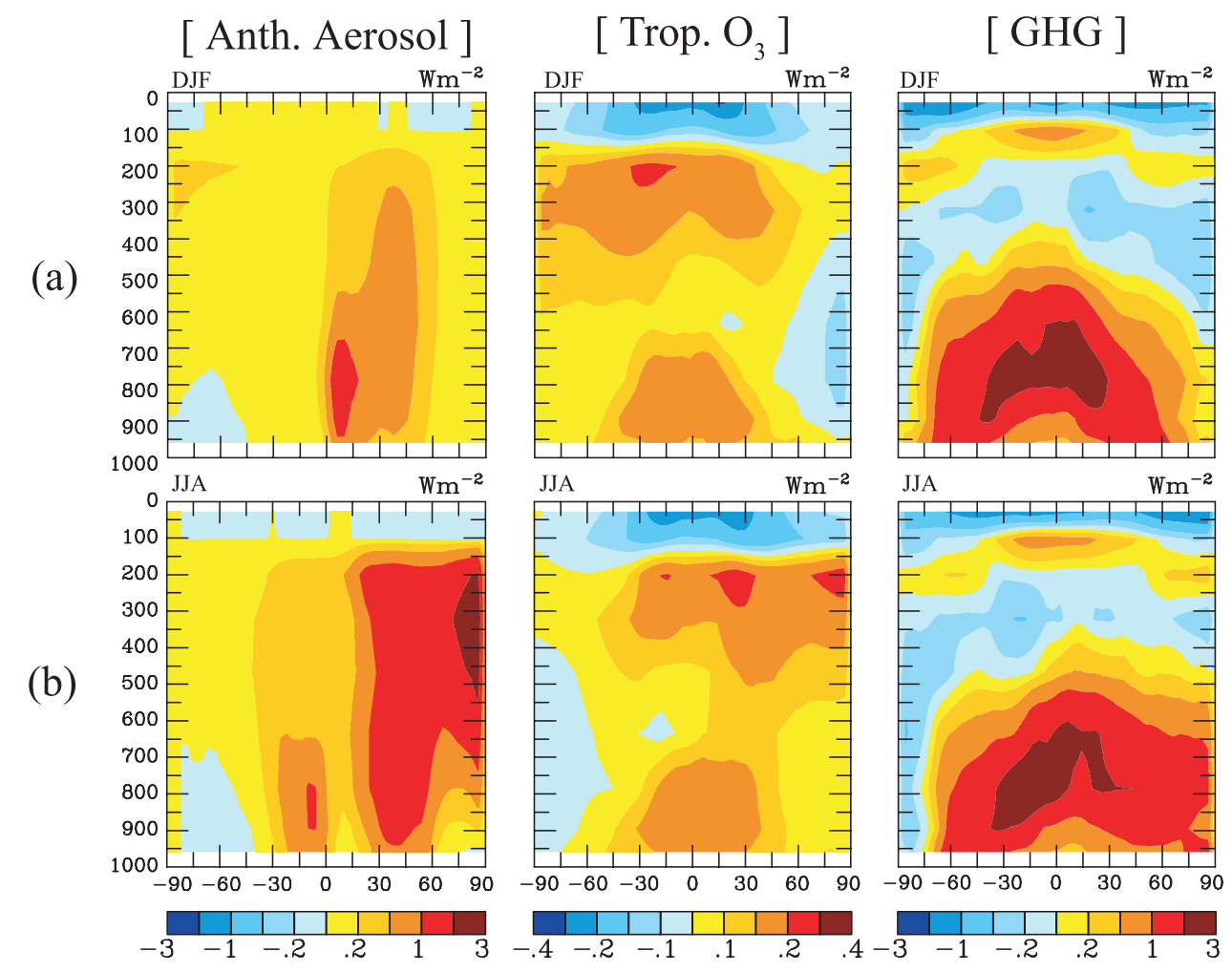

Figure 3. Latitude-pressure distribution of changes in atmospheric forcing $\left(\mathrm{W} \mathrm{m}^{-2}\right)$ in (a) DJF and (b) JJA imposed by changes of anthropogenic aerosol, tropospheric ozone, and GHG between present day and year 2100 . 
Table 3. Global and Hemispherical Annual Mean Differences of Selected Climate Parameters ${ }^{\mathrm{a}}$

\begin{tabular}{|c|c|c|c|c|c|c|c|c|c|}
\hline & \multicolumn{3}{|c|}{$\triangle \mathrm{AER}$} & \multicolumn{3}{|c|}{$\triangle \mathrm{AERO}_{3}$} & \multicolumn{3}{|c|}{$\Delta \mathrm{GHG}$} \\
\hline & Global & $\mathrm{NH}$ & $\mathrm{SH}$ & Global & $\mathrm{NH}$ & $\mathrm{SH}$ & Global & $\mathrm{NH}$ & $\mathrm{SH}$ \\
\hline Surface Temperature, K & 0.14 & 0.29 & $(0.00)$ & 0.46 & 0.71 & 0.22 & 5.31 & 6.21 & 4.40 \\
\hline TSS, $\mathrm{K} \mathrm{km}^{-1 \mathrm{~b}}$ & 0.06 & 0.07 & 0.05 & 0.07 & 0.07 & 0.08 & 0.10 & 0.02 & 0.19 \\
\hline Evaporation, $\mathrm{mm} \mathrm{day}^{-1}$ & -0.03 & -0.05 & -0.02 & -0.01 & -0.03 & $(0.00)$ & 0.34 & 0.35 & 0.33 \\
\hline SS Precipitation, $\mathrm{mm}$ day $^{-1}$ & $(0.00)$ & -0.01 & $(0.00)$ & 0.01 & $(0.00)$ & 0.01 & 0.13 & 0.13 & 0.12 \\
\hline MC Precipitation, $\mathrm{mm} \mathrm{day}^{-1}$ & -0.03 & $(0.01)$ & -0.06 & -0.02 & 0.03 & -0.07 & 0.21 & 0.34 & 0.09 \\
\hline SS Cloud Fraction, \% & 0.15 & 0.38 & $(-0.09)$ & 0.21 & 0.48 & $(-0.07)$ & 0.66 & 1.19 & 0.11 \\
\hline MC Cloud Fraction, \% & -0.19 & -0.11 & -0.27 & -0.24 & -0.12 & -0.36 & -0.15 & 0.24 & -0.54 \\
\hline Atmospheric Water Content, mm & 0.41 & 0.74 & 0.08 & 0.89 & 1.31 & 0.47 & 8.06 & 8.90 & 7.21 \\
\hline TOA Net SW Flux, $\mathrm{W} \mathrm{m}^{-2}$ & 0.45 & 0.88 & $(-0.02)$ & 0.70 & 1.09 & -0.31 & 0.84 & 1.59 & 0.10 \\
\hline TOA Net LW Flux, $\mathrm{W} \mathrm{m}^{-2}$ & -0.52 & -0.43 & -0.61 & -0.75 & -0.66 & -0.84 & -1.19 & -1.27 & -1.10 \\
\hline Ground Albedo, \% & -0.03 & -0.08 & 0.03 & -0.16 & -0.33 & $(0.01)$ & -1.80 & -3.33 & -0.28 \\
\hline Surface Net SW Flux, $\mathrm{W} \mathrm{m}^{-2}$ & -3.04 & -4.76 & -1.32 & -3.27 & -5.04 & -1.49 & -1.69 & -1.01 & -2.37 \\
\hline Surface Net LW Flux, $\mathrm{W} \mathrm{m}^{-2}$ & 0.90 & 1.49 & 0.33 & 1.48 & 2.08 & 0.88 & 7.55 & 7.75 & 7.36 \\
\hline Surface SH Flux, $\mathrm{W} \mathrm{m}^{-2}$ & 1.14 & 1.93 & 0.35 & 1.36 & 2.11 & 0.61 & 3.67 & 3.36 & 4.02 \\
\hline Surface LH Flux, $\mathrm{W} \mathrm{m}^{-2}$ & 0.95 & 1.34 & 0.55 & 0.41 & 0.85 & $(-0.05)$ & -9.79 & 29.21 & 38.71 \\
\hline
\end{tabular}

${ }^{a}$ Differences insignificant relative to the $95 \%$ confidence intervals are parenthesized. The usual $t$-test takes into account the temporal correlation in each set of sample data (i.e., in our cases here, the global/hemispherical annual average of the climate variable of interest in the last 30 years in each simulation), and therefore the sample size $n$ and $m$ is reduced to the equivalent sample size $n_{\mathrm{e}}$ and $m_{\mathrm{e}}$ (see equation (6) in Zwiers and von Storch [1995]). The difference in mean is significant if it exceeds the $95 \%$ confidence interval, which equals to $1.98 \times s \times\left(1 / n_{\mathrm{e}}+1 / m_{\mathrm{e}}\right)^{0.5}$ if $n_{\mathrm{e}}+m_{\mathrm{e}} \geq 30$, where $s$ is the pooled standard deviation or is determined by a lookup table if $n_{\mathrm{e}}+m_{\mathrm{e}}<30$. For more detailed explanation of the "usual" $t$-test and the lookup tables, please refer to the work of Zwiers and von Storch [1995].

${ }^{\mathrm{b}}$ Tropospheric static stability (TSS) is defined as the slope of the vertical change of potential temperature throughout the troposphere.

$\mathrm{NH}$ midlatitudes and higher biomass burning emissions over the Sahel region. In JJA, the large aerosol-induced forcing $\left(1-2 \mathrm{~W} \mathrm{~m}^{-2}\right)$ at $30^{\circ}-60^{\circ} \mathrm{N}$ in the low- to the midtroposphere can be explained by stronger solar insolation, while the increasing biomass burning over the Amazon and southern Africa is responsible for the increase in the lower atmosphere between $0^{\circ}$ and $30^{\circ} \mathrm{S}$. A maximum atmospheric forcing of $2-3 \mathrm{~W} \mathrm{~m}^{-2}$ is predicted in the middle to high troposphere (around $350 \mathrm{hPa}$, approximately at an altitude of $8-9 \mathrm{~km}$ ) in the northern high latitudes, which can be explained by the stronger convection in $\mathrm{NH}$ in JJA than in DJF; strongly absorbing BC and slightly absorbing $\mathrm{OC}$ are transported to high latitudes while being transported to middle to high troposphere, leading to the maximum forcing over the high-albedo surface of snow and low-level cloud deck. When compared to the AeroCom model simulations [Schulz et al., 2006], stronger polar transport of black carbon is predicted in this study than other AeroCom models besides GISS model E, indicating less efficient washout processes or more efficient vertical transport in GISS GCM [Schulz et al., 2006]. Therefore the predicted positive atmospheric aerosol forcing (and hence the predicted tropospheric warming in section 3) in the northern polar region in this study should be considered as a higher-end estimate, owing to the higher loads of internally mixed black carbon predicted in northern high latitudes.

[15] The change of tropospheric $\mathrm{O}_{3}$ is predicted to increase atmospheric forcing through the entire troposphere by +0.1 to $+0.3 \mathrm{~W} \mathrm{~m}^{-2}$ (Figure 3), especially in the altitude range of 150 to $300 \mathrm{hPa}$ in the summer hemisphere because of the predicted increase in $\mathrm{O}_{3}$ concentrations and the high incoming SW radiation. In addition, the increase of tropospheric $\mathrm{O}_{3}$ blocks more outgoing LW fluxes and decreases atmospheric forcing in the stratosphere, especially over the Tropics. The GHG-induced positive atmospheric forcing change maximizes between 900 and $600 \mathrm{hPa}\left(2-3 \mathrm{~W} \mathrm{~m}^{-2}\right)$ because GHG has to compete for LW absorption with water vapor, of which the concentration is highest in the lowest layer and decreases with altitude in the troposphere. Above $600 \mathrm{hPa}$, the GHG LW absorption saturates and the atmospheric forcing shows a relatively small change. A negative GHG atmospheric forcing between 200 and $400 \mathrm{hPa}$ is predicted because the upward LW flux entering the upper troposphere (UT)/lower stratosphere (LS) from below is reduced due to the stronger GHG LW absorption in the lower troposphere, and also because more LW radiation in the UT/LS is lost to space owing to increased GHG LW emission. The distribution of GHG-induced atmospheric forcing shows less latitudinal and seasonal variations when compared to those induced by changes of aerosol and $\mathrm{O}_{3}$.

\section{Estimated Changes in Global Climate}

[16] Table 3 summarizes globally and hemispherically averaged annual mean differences of selected variables in $\triangle \mathrm{AER}, \triangle \mathrm{AERO}_{3}$, and $\triangle \mathrm{GHG}$, with changes insignificant at a $95 \%$ confidence level parenthesized. The $95 \%$ intervals are calculated based on the two-sample "usual" $t$-test [Zwiers and von Storch, 1995; Chung and Seinfeld, 2005] (see footnote in Table 3).

\subsection{Surface Air Temperature}

[17] As shown in Table 3, the change in anthropogenic aerosols ( $\triangle$ AER), aerosols plus tropospheric ozone $\left(\triangle \mathrm{AERO}_{3}\right)$, and $\mathrm{GHG}(\triangle \mathrm{GHG})$ from present day to year 2100 is predicted to increase the global annual mean surface air temperature by $0.14,0.46$, and $5.31 \mathrm{~K}$, respectively. The difference between $\triangle \mathrm{AER}$ and $\triangle \mathrm{AERO}_{3}$ shows that the change in tropospheric ozone alone is predicted to lead to a warming by $0.32 \mathrm{~K}$. With the total organic aerosol (TOA) instantaneous forcing perturbations given in section 2.3 and the above equilibrium global annual mean surface temperature responses, the predicted climate sensitivity, defined as the ratio of equilibrium global annual mean surface air temperature change to the global annual mean radiative 
[ $\triangle \mathrm{AER}$ ]

(a)

(b)
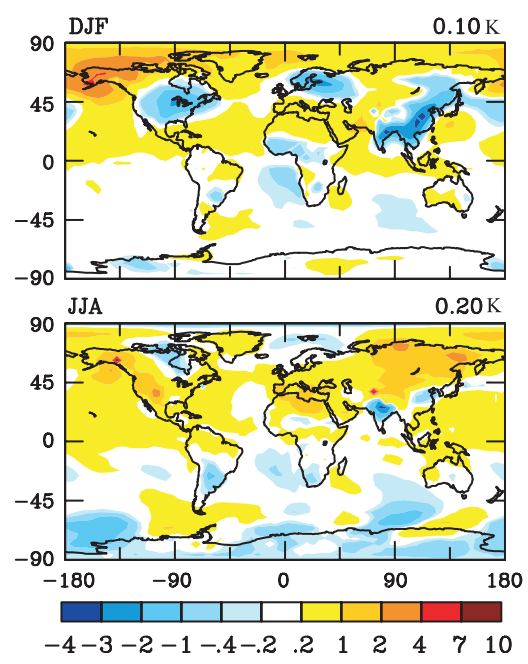

$\left[\triangle \mathrm{AERO}_{3}\right]$
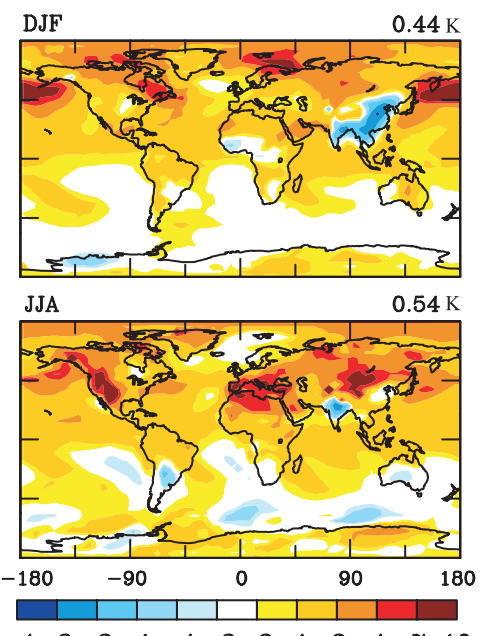

$[\Delta \mathrm{GHG}]$
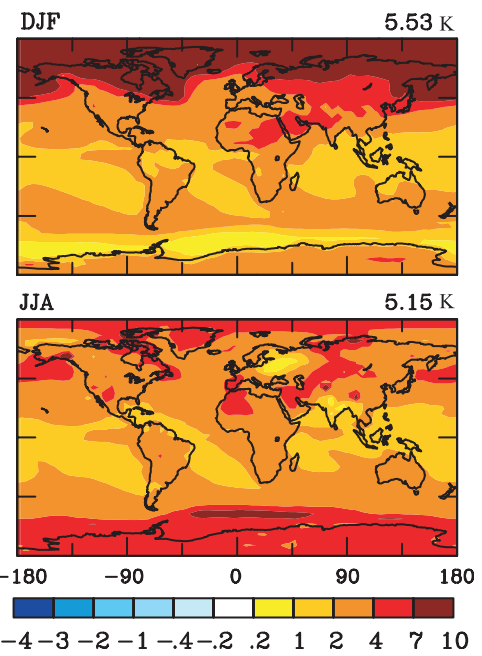

Figure 4. Predicted change in global surface air temperature (K) in (a) DJF and (b) JJA. Note that the color scale for $\triangle \mathrm{GHG}$ differs from the other two.

forcing, is $0.78,0.49$, and $0.81 \mathrm{~K} \mathrm{~m}^{2} \mathrm{~W}^{-1}$ for aerosols, ozone, and GHG, respectively. Note that for radiative forcing of tropospheric aerosols, the instantaneous forcing at TOA is more often adopted in the literature, while for GHG, the adjusted forcing, i.e., the radiative forcing at tropopause after the stratospheric temperature adjusts to radiative equilibrium, is normally used [e.g., IPCC, 2001]. Here we use the instantaneous forcing at the tropopause to calculate the climate sensitivity. For GHG, the adjusted forcing is typically $10-20 \%$ lower than the instantaneous forcing, while for aerosols the two are approximately equal [Hansen et al., 1997].

[18] Maps of surface air temperature change in DJF and JJA are shown in Figure 4. The slight global warming of $0.14 \mathrm{~K}$ predicted for the aerosol-induced climate change ( $\triangle \mathrm{AER}$ ) is actually a result of regional cooling (in areas predicted to have a substantial increase in scattering aerosols) offset by regional warming (due to internally mixed, BC-containing particles over highly reflective surfaces). In DJF, strong aerosol-induced regional cooling is predicted to occur in eastern China, Indochina, India, the Sahel, Western
Europe, and eastern United States; regional warming is predicted over midlatitude deserts and northern high latitudes. In JJA, because of the larger decrease in $\mathrm{SO}_{4}^{2-}$ and smaller increase in $\mathrm{NO}_{3}^{-}$and $\mathrm{POA}$, prevailing warming appears globally except in India, southwestern Africa, and South America where $\mathrm{SO}_{4}^{2-}$ is still increasing from present day to year 2100. The predicted regional cooling in DJF due to anthropogenic aerosol direct effect over East and South Asia is addressed in more detail in section 4. Figure 5 displays the predicted zonal mean surface air temperature change. Aerosol-induced warming is concentrated in the $\mathrm{NH}$ and is maximized in the high latitudes. The predicted annual mean surface air temperature change in the $\mathrm{NH}$ is $0.29 \mathrm{~K}$, while in the sensible heat $(\mathrm{SH})$ the surface air temperature shows virtually no change. The resulting interhemispheric temperature gradient can potentially affect the pattern of global circulation, as will be discussed in section 3.3.

[19] When both changes in aerosols and ozone are considered $\left(\triangle \mathrm{AERO}_{3}\right)$, the ozone adds to the aerosol-induced climate change a prevailing surface warming. Altogether, the global annual mean surface air temperature is predicted
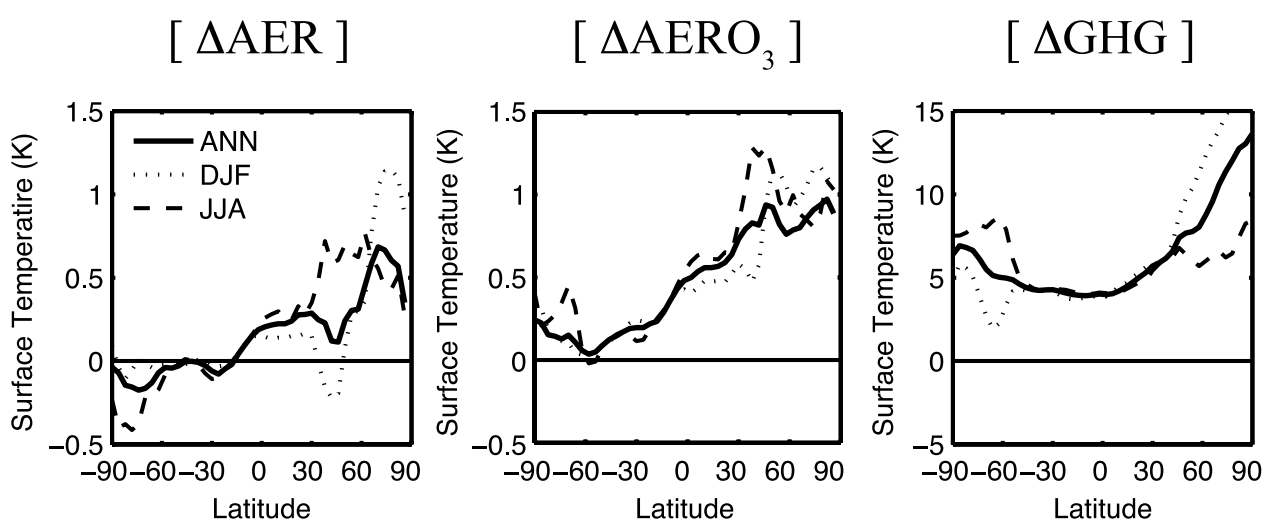

Figure 5. Predicted zonal mean changes in surface air temperature $(\mathrm{K})$. Note that the vertical scale for $\triangle$ GHG differs from the other two. 


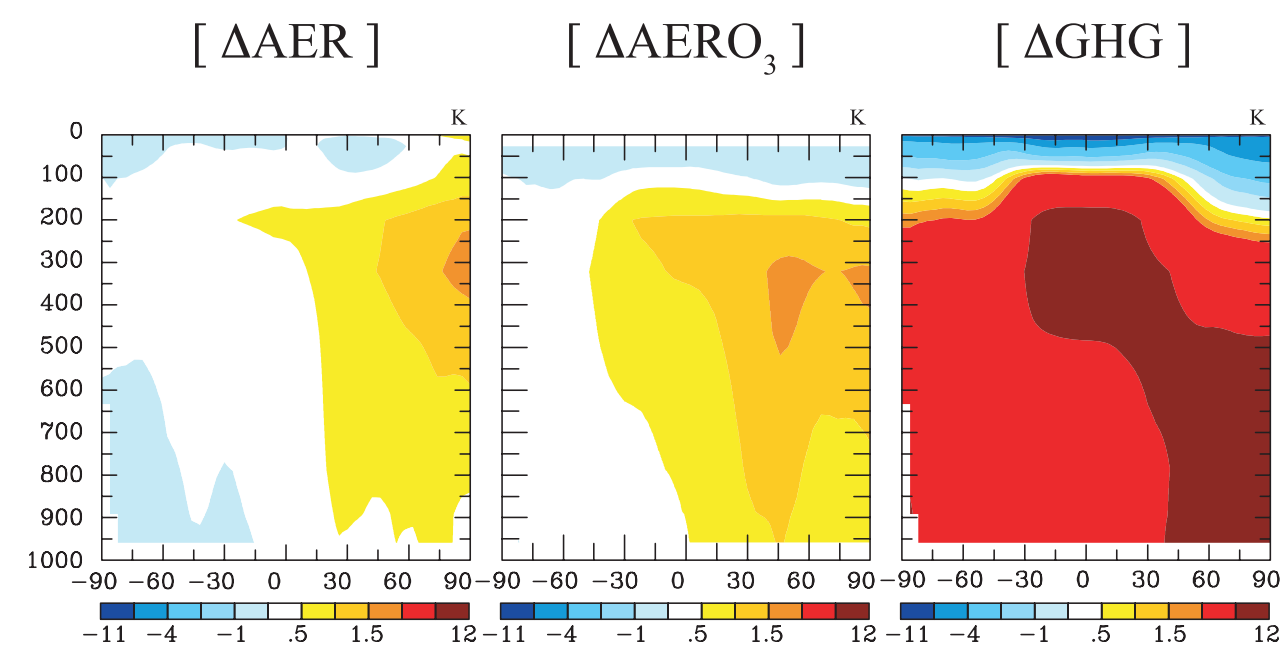

Figure 6. Latitude-pressure distribution of changes in annual mean temperature (K).

to increase by $0.46 \mathrm{~K}$, with local maxima located in the urban areas of Europe, Central Asia, the Middle East, and North America, and downwind of the biomass burning regions in South Africa and South America. Over eastern China and India, the $\mathrm{O}_{3}$-induced warming does not override the strong aerosol surface cooling, and a regional temperature decrease is still predicted under the scenario of $\triangle \mathrm{AERO}_{3}$. The geographic distribution of the predicted $\mathrm{O}_{3}$-induced surface temperature change is consistent with that of Mickley et al. [2004], who studied the climate response to changes in tropospheric ozone from preindustrial times to present day using the same GCM as in the present study.

[20] As a result of GHG increase from present day to $2100(\Delta \mathrm{GHG})$, substantial warming is predicted in the northern high latitudes owing to ice-albedo feedback, as well as in the desert areas of China, central Asia, Middle East, and Northern Africa (Figure 4). The temperature responses are always greater in the NH than the SH (Figure 5), due to heat uptake by the Southern Ocean. The predicted hemispheric mean surface temperature difference is about $1.81 \mathrm{~K}$.

\subsection{Tropospheric Temperature and Stability}

[21] Figure 6 displays the zonally averaged vertical distribution of annual mean temperature change. Change in aerosols from present day to 2100 is predicted to lead to maximum warming in the midtroposphere north of $30^{\circ} \mathrm{N}$ ( $\triangle \mathrm{AER}$ ), corresponding to the location of maximum atmospheric forcing increase (Figure 3 ). The pattern of maximum warming in the tropical midtroposphere owing to GHG change $(\triangle \mathrm{GHG})$ is similar to that of other GHGdriven GCM equilibrium [e.g., Manabe and Wetherald, 1975; Hansen et al., 1997] and transient [e.g., IPCC, 2001] simulations. This pattern can be explained by enhanced thermal radiative heating due to increased water vapor, as well as by the vertical temperature convective adjustment toward the moist adiabatic lapse rate [Manabe and Wetherald, 1975]. The enhanced midtropospheric heating induced by GHG leads to a more stable atmosphere in low to midlatitudes, while in high latitudes the stability decreases owing to large surface warming. The change in stability can affect the Tropical Hadley circulation, as will be discussed in section 3.3. The result of $\triangle \mathrm{AERO}_{3}$ shows that tropospheric ozone is predicted to lead to additional tropospheric warming and stratospheric cooling beyond that of $\triangle \mathrm{AER}$ with the pattern similar to that induced by GHG change but of a considerably smaller magnitude.

\subsection{Global Circulation}

[22] Figures $7 \mathrm{a}$ and $7 \mathrm{~b}$ display the zonal mean of the mass stream function in the baseline simulation PD and its change resulting from change in aerosols $(\triangle \mathrm{AER})$ and $\mathrm{GHG}$ $(\Delta \mathrm{GHG})$. The aerosol-induced change in the stream function has comparable magnitude to that induced by GHG, likely owing to the larger ratio of change in interhemispheric surface temperature gradient to change in global annual mean temperature in the aerosol perturbation $(0.29 \mathrm{~K} / 0.14 \mathrm{~K}$, and for $\Delta \mathrm{GHG}, 1.81 \mathrm{~K} / 5.31 \mathrm{~K})$. The change in aerosols is predicted to impose an anomalous counterclockwise flow located between $5^{\circ} \mathrm{N}$ and $5^{\circ} \mathrm{S}(\triangle \mathrm{AER})$, which is out-of-phase to the DJF Hadley circulation and indicates the weakening of the Hadley cell, while during JJA, this predicted aerosolinduced anomalous flow becomes in-phase and thus strengthens the Hadley circulation. This pattern of stream function change is related to the enhanced interhemispheric temperature difference in the aerosol perturbation. In the GHG perturbation $(\triangle \mathrm{GHG})$, the Hadley cell is weakened as a result of the pronounced increase of static stability over the Tropics [Knutson and Manabe, 1995; Mitas and Clement, 2006], especially in DJF; only the ascending branch in the convection zone north of the equator is strengthened and penetrates higher in response to temperature and moisture increase. A similar change in Hadley circulation induced by transient GHG warming is predicted by most of the IPCC Fourth Assessment Report (AR4) GCMs, although not in the reanalyses data. We refer the reader to the work of Mitas and Clement [2006] for detailed analyses and discussion.

[23] The changes in zonal wind component are shown in Figures $7 \mathrm{c}$ and $7 \mathrm{~d}$. The change of zonal wind due to change in aerosols ( $\triangle \mathrm{AER}$ ) is relatively small (within $2 \mathrm{~m} \mathrm{~s}^{-1}$ ). The core of the jet stream is predicted to be slightly strengthened in the NH in DJF and in the SH in JJA. This can be induced by a stronger latitudinal temperature gradient in the lower troposphere between the Tropics and the 


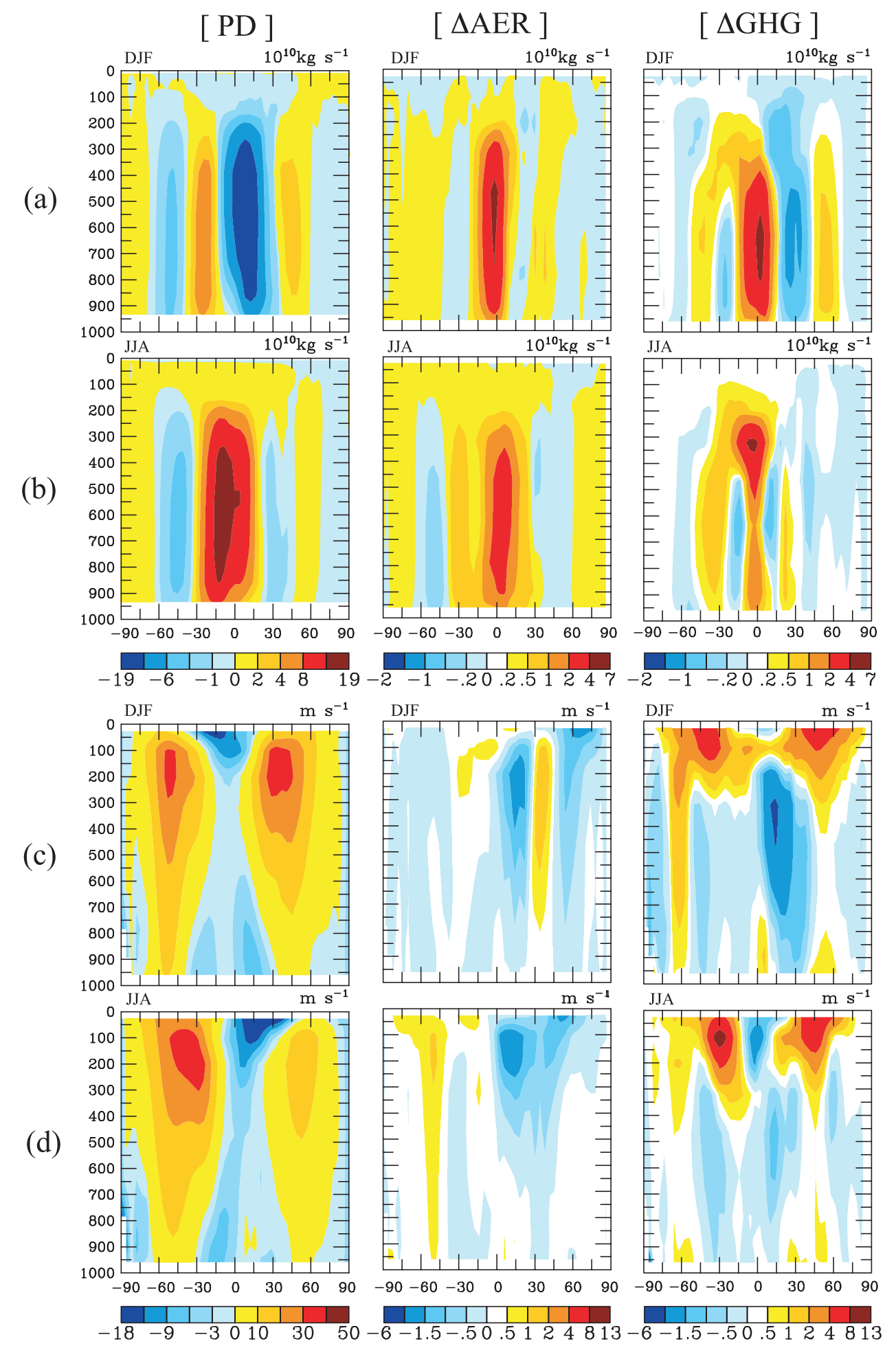

Figure 7. Latitude-pressure distribution of stream function $\left(10^{10} \mathrm{~kg} \mathrm{~s}^{-1}\right.$, positive values indicate counterclockwise flow) in (a) DJF and (b) JJA, and zonal wind $\left(\mathrm{m} \mathrm{s}^{-1}\right.$, positive values indicate westerlies) in (c) DJF and (d) JJA. Left: seasonal mean in simulation PD; middle: $\triangle$ AER; right: $\Delta$ GHG.

midlatitudes, a result of surface cooling around $25^{\circ}-45^{\circ} \mathrm{N}$ in DJF, and cooling in the Southern Ocean in JJA. In the GHG-induced change $(\Delta \mathrm{GHG})$, the increasing easterlies in the midtroposphere in low and midlatitudes are a result of decreasing latitudinal gradient of surface temperature.
[24] Note that the change in global circulation is influenced heavily by the predicted change in the thermodynamic structure of the atmosphere and the convective cumulus parameterization; we note that these predictions can be quite model-dependent. Since there is only one vertical strato- 
$[\triangle \mathrm{AER}]$

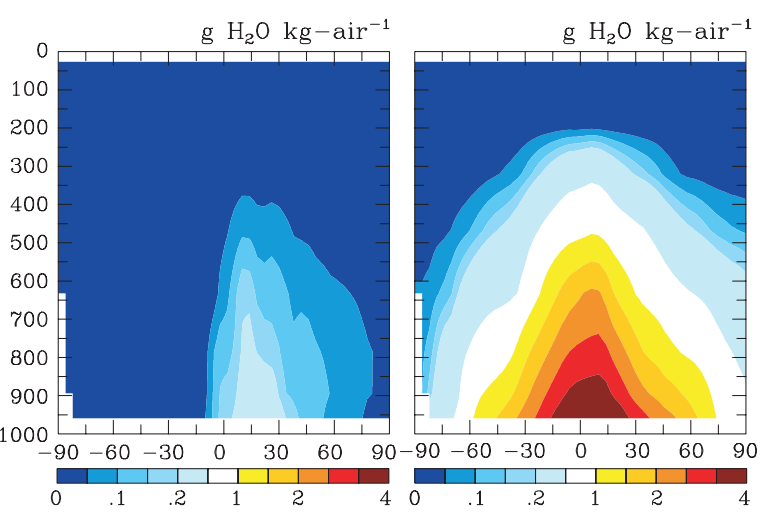

(b)

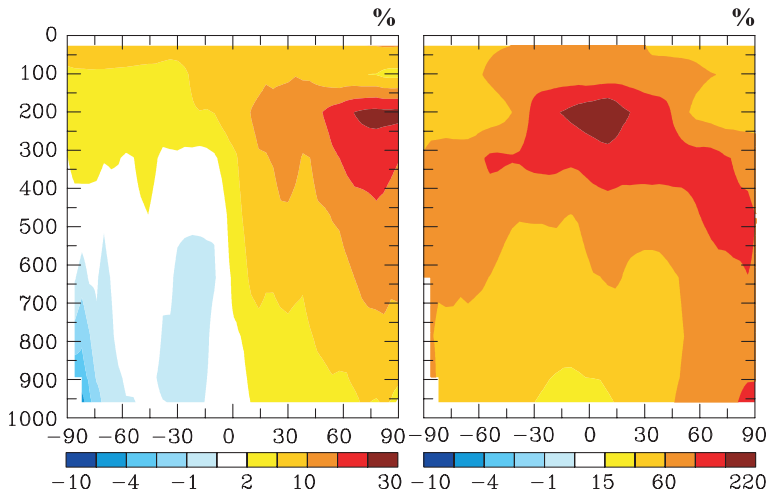

Figure 8. Latitude-pressure distribution of changes in annual mean specific humidity: (a) absolute change ( $\mathrm{g}-\mathrm{H}_{2} \mathrm{O}$ $\mathrm{kg}$-air ${ }^{-1}$ ) and (b) relative change (\%). Note that the color scale in Figure $8 \mathrm{~b}$ differs between $\triangle \mathrm{AER}$ and $\triangle \mathrm{GHG}$.

spheric layer in the 9-layer GISS GCM II', we do not analyze the changes in stratospheric winds. The changes of stream function and zonal wind induced by aerosol plus ozone $\left(\triangle \mathrm{AERO}_{3}\right)$ are similar to those induced by aerosols only, and therefore are not shown here.

\subsection{Hydrological Cycle}

[25] Changes in temperature and global circulation have important effects on the global hydrological cycle, including the distribution of water vapor, evaporation, precipitation, strength and frequency of moist convection, and cloud coverage. On the other hand, the increase of water vapor creates a positive feedback on warming.

[26] Figure 8 shows the latitude-pressure distribution of the annual mean difference in specific humidity. The absolute increase of water vapor (Figure 8a) always maximizes in the tropical lower troposphere; perturbations from changing aerosols from present day to $2100(\triangle \mathrm{AER})$ is predicted to be around $0.2-0.8 \mathrm{~g}-\mathrm{H}_{2} \mathrm{O} \mathrm{kg-air}{ }^{-1}$, and from changing GHG $(\Delta \mathrm{GHG})$, around 3-4 g- $\mathrm{H}_{2} \mathrm{O} \mathrm{kg-air}{ }^{-1}$. On the other hand, the pattern of the relative change in specific humidity (Figure 8b) is controlled largely by the pattern of temperature change through the Clausius-Clapeyron relationship. A relative increase in water vapor in the case of $\triangle \mathrm{AER}$ concentrates in high latitudes in the $\mathrm{NH}$ (around 10-30\%) because of the predicted warming, whereas in $\mathrm{SH}$, the relative change is insignificant $(<5 \%)$. The pattern predicted with GHG perturbation ( $\Delta \mathrm{GHG}$ ) shows a doubling to tripling of water vapor in the Tropical upper troposphere (because of the strong water vapor feedback) and low to midtroposphere in the northern high latitudes (owing to amplified warming in the Arctic region); the minimum of the relative increase in humidity (around 15\%) appears in the Tropics near surface (location of maximum absolute increase) because humidity here is already much higher and the predicted warming is as significant as near the Tropical tropopause.

[27] As given in Table 3, globally the aerosol perturbation $\triangle$ AER produces a slight decrease in total precipitation $\left(0.03 \mathrm{~mm} \mathrm{day}^{-1}\right)$, most of which is related to lower convective precipitation. The change in global mean precipitation is controlled by the change in global evaporation rate, which also decreases by around $0.03 \mathrm{~mm}$ day $^{-1}$ due to surface cooling. The decrease in the global annual mean of moist convective (MC) cloud cover $(0.19 \%)$ is balanced by the increase in large-scale supersaturation (SS) cloud cover $(0.15 \%)$, and therefore the total cloud cover remains essentially unchanged. Note that the above changes are due only to aerosol direct forcing; aerosol indirect effects are not considered. The results in $\triangle \mathrm{AERO}_{3}$ show that the inclusion of ozone change is predicted to lead to, in addition to the aerosol-induced change, a slight increase in total precipitation and SS cloud, but a small decrease in MC cloud. The climate effect of increasing GHG on the hydrological cycle is similar, but with much more pronounced magnitude, to that of tropospheric ozone, as revealed by $\Delta \mathrm{GHG}$. The GHG perturbation leads to a predicted increase in annual mean total precipitation as a result of increasing evaporation $\left(0.34 \mathrm{~mm} \mathrm{day}^{-1}\right)$. The SS cloud cover increases $(0.66 \%)$ owing to increasing humidity, whereas $\mathrm{MC}$ cloud cover decreases $(0.15 \%)$ because of the enhanced tropospheric static stability over the Tropics, especially over the southern equatorial convection zone, which we will return to later.

[28] The zonal mean change in excess precipitation (total precipitation minus evaporation) and $\mathrm{MC}$ precipitation is shown in Figure 9, while the zonal mean change in $\mathrm{MC}$ and high cloud cover are shown in Figure 10. The predicted $\triangle$ AER excess precipitation change is confined mainly to the Tropics. The ascending/descending branch of the anomalous flow in $\triangle \mathrm{AER}$ (Figures $7 \mathrm{a}$ and $7 \mathrm{~b}$ ) results in an increase/decrease in MC precipitation $\left(\sim 0.2 \mathrm{~mm}^{\text {day }}{ }^{-1}\right)$, MC cloud fraction $(\sim 0.01)$, and high cloud fraction $(\sim 0.01-0.02)$ in the northern/southern equatorial region. The small dip of $\mathrm{MC}$ cloud around $30^{\circ} \mathrm{N}(0.4 \%)$ may be related to the increase in atmospheric stability associated with surface cooling. In $\Delta \mathrm{GHG}$, precipitation significantly exceeds evaporation between $0^{\circ}$ and $10^{\circ} \mathrm{N}$ by as much as $1 \mathrm{~mm}$ day $^{-1}$, mostly related to the large predicted increase in $\mathrm{MC}$ precipitation as a result of stronger penetrating convection and additional moisture convergence, as indicated by the large increase in high cloud $(6 \%)$ over the same region. In the remainder of the Hadley cell, the circulation is weakened (Figures $7 \mathrm{a}$ and $7 \mathrm{~b}$ ) and therefore the MC cloud cover is predicted to decrease in response to weaker updraft velocity, especially in the southern equatorial zone; however, the MC precipitation shows very little change between $0^{\circ}$ and $15^{\circ} \mathrm{S}$. Outside the Tropics, the increased moisture is transported by the midlatitude eddies away from the Subtropics to middle and high latitudes. The predicted moisture 
(a)

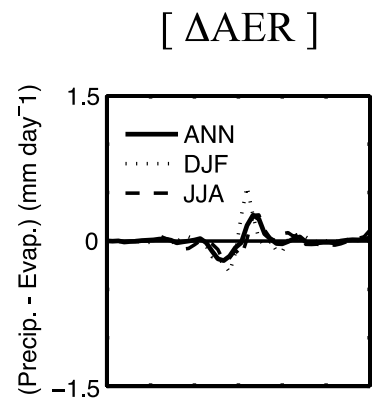

(b)
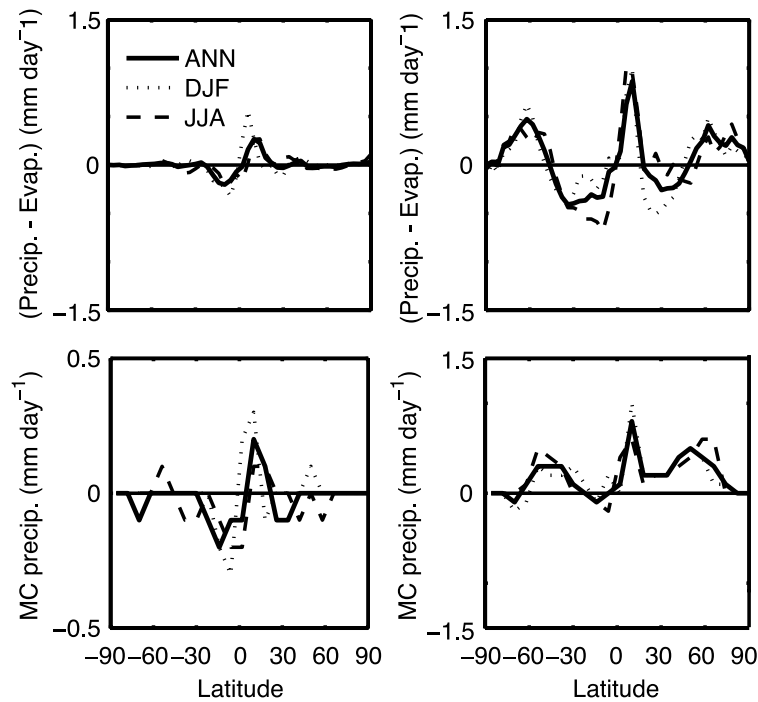

Figure 9. Predicted zonal mean changes in (a) excess precipitation (total precipitation minus evaporation, $\mathrm{mm} \mathrm{day}^{-1}$ ) and (b) moist-convective (MC) precipitation $\left(\mathrm{mm} \mathrm{day}^{-1}\right)$. Note that the vertical scales differ between $\triangle \mathrm{AER}$ and $\Delta$ GHG.

divergence associated with eddy activities explains the precipitation deficit (excess evaporation) of $0.3-0.5 \mathrm{~mm}$ day $^{-1}$ over $30^{\circ} \mathrm{N} / \mathrm{S}$ and the precipitation residue of $0.5 \mathrm{~mm}$ day $^{-1}$ around $60^{\circ} \mathrm{N} / \mathrm{S}$. The predicted response of the hydrological cycle to increased GHG is generally in agreement with previous modeling studies for the equilibrium response [e.g., Dai et al., 2001; Liepert et al., 2004] (a coupled
[ $\triangle \mathrm{AER}]$

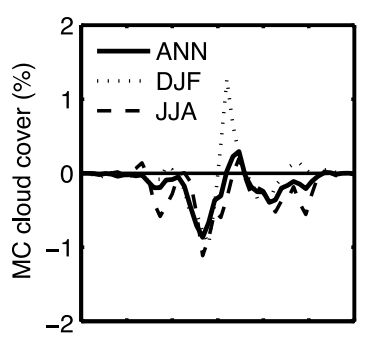

(b)

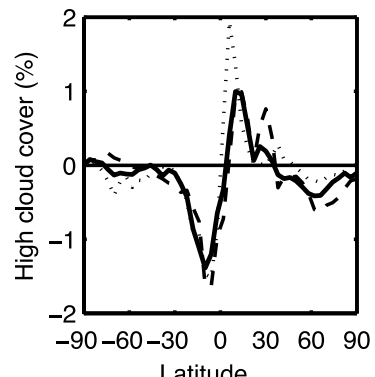

$[\Delta \mathrm{GHG}]$
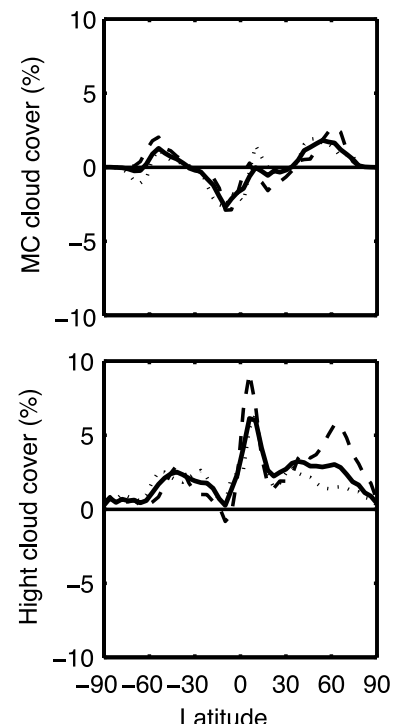

Figure 10. Predicted zonal mean changes in (a) moistconvective (MC) cloud cover (\%) and (b) high cloud cover $(\%)$. Note that the vertical scales differ between $\triangle \mathrm{AER}$ and $\Delta$ GHG. dynamic ocean is used in Dai et al. [2001]) and for the transient response [e.g., IPCC, 2001; Watterson and Dix, 2003; Held and Soden, 2006]. Note that change in aerosols ( $\triangle \mathrm{AER}$ ) does not produce the secondary peak of excess precipitation increase in high latitudes because of the relative small change in specific humidity. The pattern of precipitation and cloud cover change predicted for $\triangle \mathrm{AERO}_{3}$ is primarily the same as that for $\triangle \mathrm{AER}$, only of slightly larger magnitude, and is therefore not shown.

\subsection{Energy Budgets}

[29] Figure 11a displays the latitudinal distribution of the net shortwave radiative fluxes at TOA. The change of TOA SW flux is affected mainly by changes in cloud cover (Figure 10) as well as by changes in surface albedo. The decrease of surface albedo in NH owing to the melting of sea ice and snow leads to a large increase in downward SW flux at TOA in all three perturbations. Change in SW flux at TOA is small elsewhere in the aerosol- and aerosol-plus- $\mathrm{O}_{3}$ induced climate change, while in the GHG perturbation, the increased cloud cover in the Tropics results in increased outgoing TOA SW flux. The change of the net longwave (LW) radiative flux at TOA is shown in Figure $11 \mathrm{~b}$. Changes due only to aerosols ( $\triangle \mathrm{AER}$ ) and aerosol plus $\mathrm{O}_{3}\left(\triangle \mathrm{AERO}_{3}\right)$ are small at all latitudes. In the GHGinduced change $\Delta \mathrm{GHG}$, the strongly increased water vapor and high cloud over the Tropics blocks more outgoing LW radiation below TOA, while the amplified surface warming is responsible for the increased outgoing LW flux at high latitudes.

[30] Figure 12 shows the zonal annual mean change of absorbed SW flux, sensible heat (SH) flux, and latent heat (LH) flux at the surface. Scattering and absorption of solar radiation by aerosols is predicted to decrease the absorbed

(a)

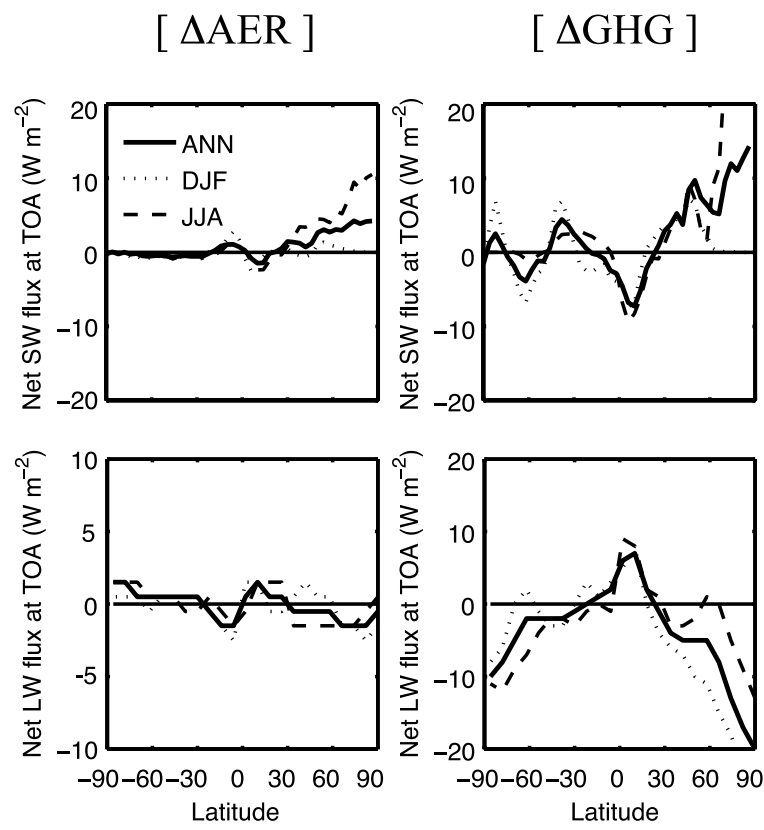

Figure 11. Predicted zonal mean changes in (a) net shortwave (SW) flux and (b) net longwave (LW) flux $\left(\mathrm{W} \mathrm{m}^{-2}\right)$ at TOA. Positive values correspond to downward fluxes. Note that the vertical scales differ between $\triangle \mathrm{AER}$ and $\Delta \mathrm{GHG}$. 
[ $\triangle \mathrm{AER}]$

(a)

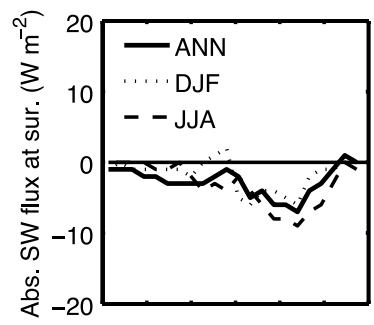

(b)

(c)
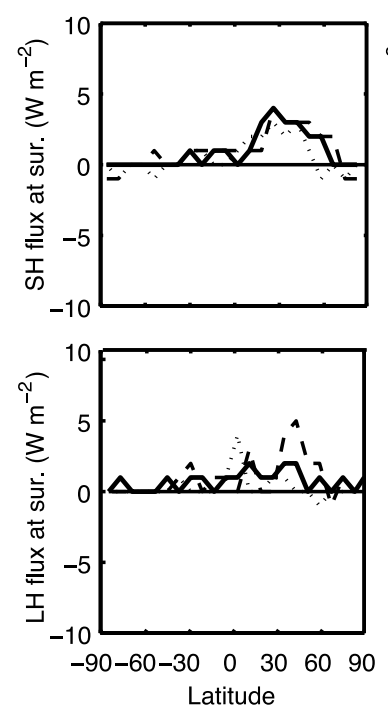

Figure 12. Predicted zonal mean changes in surface fluxes (W $\mathrm{m}^{-2}$ ) of (a) absorbed (abs.) shortwave radiation ( $\mathrm{SW}$, negative values indicate surface solar dimming), (b) sensible heat $(\mathrm{SH}$, positive values indicate flux from atmosphere into surface), and (c) latent heat ( $\mathrm{LH}$, positive values indicate decreased evaporation). Note that the vertical scales differ between $\triangle \mathrm{AER}$ and $\triangle \mathrm{GHG}$.

SW flux at the surface in most latitudes ( $\triangle$ AER), especially between $0^{\circ}$ and $60^{\circ} \mathrm{N}\left(\sim 7 \mathrm{~W} \mathrm{~m} \mathrm{~m}^{-2}\right)$ where the highest aerosol burden is located. This reduction of surface SW radiation is compensated primarily by the increase of atmosphere-to-surface SH flux and also the small decrease in surface-leaving LH flux due to evaporation suppression. The GHG-induced latitudinal distribution of the absorbed SW flux change at the surface is similar to that of the SW flux change at TOA; the increased cloud cover (Figure 10) reduces the incident solar radiation at the surface in the Tropics and in the Southern Ocean by about $10 \mathrm{~W} \mathrm{~m}^{-2}$, while in the NH subpolar and polar regions, the surface receives more $\mathrm{SW}$ radiation because of the decreased surface albedo. On the other hand, the GHG perturbation is predicted to increase downward LW flux at all latitudes (not shown) because of higher atmospheric temperature and enhanced water vapor greenhouse effect and higher downward $\mathrm{SH}$ flux due to higher atmospheric temperature. The changes in surface SW, LW and $\mathrm{SH}$ is balanced by the increased upward LH flux, especially over the middle and high latitudes, where evaporation is enhanced due to surface warming and additional exposure of water surface owing to melting of sea ice.

\section{Estimated Regional Climate Changes in Asia in Winter}

[31] The inhomogeneous geographical distribution of direct radiative forcing of anthropogenic aerosols (Figure 2) leads to potential impacts on regional climate, one example of which is the significant regional cooling in East and South Asia, especially in DJF (Figure 4a, $\triangle$ AER). In this section, the predicted regional climate change in East and South Asia in DJF is analyzed (see Figure 13 for locations of grid cells selected for statistical calculation). Detailed analyses of regional-scale climate changes is limited by the coarse horizontal resolution of the GISS GCM II' and the q-flux ocean in this study, particularly in regions influenced by complicated monsoon systems, such as Asia. Presented here are only the most significant and spatially extensive changes of regional temperature, precipitation, and synoptic winds directly attributable to aerosol surface cooling predicted in the equilibrium simulations with a mixed layer ocean model. Responses associated with changes in monsoon dynamics and sea surface temperature (SST) are beyond the scope of the current study.

[32] If only perturbed by the significant regional increases in aerosol burden from 2000 to 2100 ( $\triangle \mathrm{AER}$ ), the East and South Asia continent is predicted to undergo substantial cooling by aerosol direct effect. Table 4 summarizes the DJF mean changes of key parameters $\left(\triangle \mathrm{AER}, \triangle \mathrm{AERO}_{3}\right.$, and $\triangle \mathrm{GHG}$ ) over these regions. In DJF when the aerosol burden increase is largest due to enhanced emissions from biofuel burning and decreased wet removal in the dry season, anthropogenic aerosols (see $\triangle \mathrm{AER}$ ), through only their direct effect, are predicted to reduce the regional mean SW flux absorbed at the surface in DJF by $22.2 \mathrm{~W} \mathrm{~m}^{-2}$ in East Asia and $18.9 \mathrm{~W} \mathrm{~m}^{-2}$ in South Asia. The reduction in surface SW flux, though balanced by increased atmosphereto-surface $\mathrm{SH}$ and/or LW fluxes, still leads to a strong decrease in mean surface temperature $(2.5 \mathrm{~K}$ in East Asia and $1.9 \mathrm{~K}$ in South Asia). In East Asia, the cooler surface results in less evaporation $\left(0.3 \mathrm{~mm} \mathrm{day}^{-1}\right)$ and higher tropospheric stability $\left(0.3 \mathrm{~K} \mathrm{~km}^{-1}\right)$, which effectively slows down the local hydrological cycle and leads to a significant decrease in total precipitation by $0.7 \mathrm{~mm}_{\text {day }}{ }^{-1}$. In South

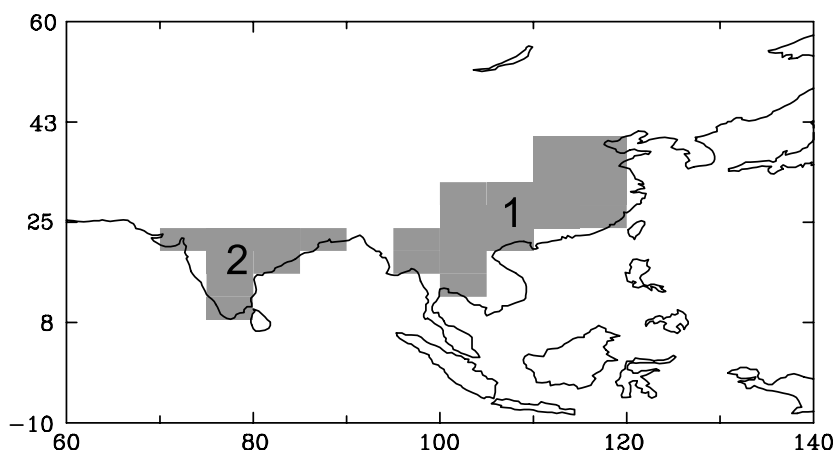

Figure 13. Regions (shaded) for calculating the statistics of regional climate change presented in Table 4: (1) East Asia and (2) South Asia. 
Table 4. Regional Mean Differences of Selected Climate Parameters in DJF Over East and South Asia ${ }^{\mathrm{a}}$

\begin{tabular}{|c|c|c|c|c|c|c|}
\hline & \multicolumn{3}{|c|}{ (1) East Asia } & \multicolumn{3}{|c|}{ (2) South Asia } \\
\hline & $\triangle \mathrm{AER}$ & $\triangle \mathrm{AERO}_{3}$ & $\Delta \mathrm{GHG}$ & $\triangle \mathrm{AER}$ & $\triangle \mathrm{AERO}_{3}$ & $\Delta \mathrm{GHG}$ \\
\hline Surface Temperature, K & -2.51 & -2.14 & 5.82 & -1.85 & -1.11 & 5.09 \\
\hline TSS, $\mathrm{K} \mathrm{km}^{-1 \mathrm{~b}}$ & 0.26 & 0.28 & 0.26 & 0.16 & 0.18 & 0.47 \\
\hline Evaporation, mm day ${ }^{-1}$ & -0.29 & -0.26 & 0.37 & 0.12 & 0.14 & 0.23 \\
\hline SS Precipitation, mm day ${ }^{-1}$ & -0.37 & -0.26 & 0.08 & -0.08 & $(-0.07)$ & $(-0.05)$ \\
\hline MC Precipitation, $\mathrm{mm} \mathrm{day}^{-1}$ & -0.12 & -0.07 & $(0.27)$ & -0.06 & -0.04 & $(0.03)$ \\
\hline Ground Albedo, \% & 1.90 & 1.87 & -2.59 & 0.27 & 0.26 & -0.12 \\
\hline Surface Net SW Flux, $\mathrm{W} \mathrm{m}^{-2}$ & -22.16 & -23.26 & $(-1.29)$ & -18.87 & -19.58 & -2.83 \\
\hline Surface Net LW Flux, $\mathrm{W} \mathrm{m}^{-2}$ & $(0.18)$ & $(0.86)$ & 4.73 & $(2.33)$ & 4.03 & $(1.19)$ \\
\hline Surface SH Flux, $\mathrm{W} \mathrm{m}^{-2}$ & 0.87 & 10.26 & 4.02 & 12.65 & 12.22 & 3.95 \\
\hline Surface LH Flux, $\mathrm{W} \mathrm{m}^{-2}$ & 4.73 & 4.46 & -6.97 & $(-0.23)$ & $(-0.70)$ & -1.94 \\
\hline
\end{tabular}

${ }^{\mathrm{a}}$ Figure 13 shows the regions over which the statistics of the usual $t$-test are computed. Differences insignificant relative to the $95 \%$ confidence intervals are parenthesized.

Asia, however, the predicted regional mean precipitation only decreases slightly by $0.1 \mathrm{~mm} \mathrm{day}^{-1}$ because of the smaller change in evaporation rate $\left(0.1 \mathrm{~mm} \mathrm{day}^{-1}\right)$. If the combined aerosol-ozone climate effect $\left(\triangle \mathrm{AERO}_{3}\right)$ is considered, the mean surface temperature is predicted to decrease by 2.1 and $1.1 \mathrm{~K}$ over East and South Asia, respectively. The regional mean changes in precipitation and surface energy fluxes are similar to those predicted for the aerosol-only perturbation ( $\triangle \mathrm{AER})$.

[33] The direct cooling resulting from changes in aerosol from 2000 to 2100 over East and South Asia affects precipitation as well as the synoptic-scale wind flow. The geographic distribution of predicted changes in DJF precipitation, sea level pressure, and surface wind field over East and South Asia are displayed in Figure 15. The aerosol-induced surface cooling is predicted to induce an anomalous high pressure $(2-4 \mathrm{hPa})$ over the continental area of East and South
Asia (Figure 14b), including southern China, Indochina, the Tibetan Plateau, and the Indian subcontinent. Precipitation over land in East Asia and the north and central Indian Subcontinent decreases in response to more cold, dry air outflow resulting from the anomalous high (Figure 14a). On the other hand, in the western Subtropical Pacific $\left(115^{\circ}-\right.$ $\left.135^{\circ} \mathrm{E}, 20^{\circ}-30^{\circ} \mathrm{N}\right)$ and in the north Indian Ocean $\left(0^{\circ}-8^{\circ} \mathrm{N}\right)$, precipitation increases in response to the enhanced convergence associated with the change in wind pattern. A substantial rainfall decrease over the south Indian Ocean and western Tropical Pacific is also predicted.

[34] It is of interest to compare the regional climate changes in DJF owing to the direct effect of anthropogenic aerosols to those owing to GHG warming. The predicted change in East and South Asia predicted from GHG forcing alone $(\triangle \mathrm{GHG})$ in this study is generally in agreement with other simulations [Bhaskaran and Mitchell, 1998; IPCC,

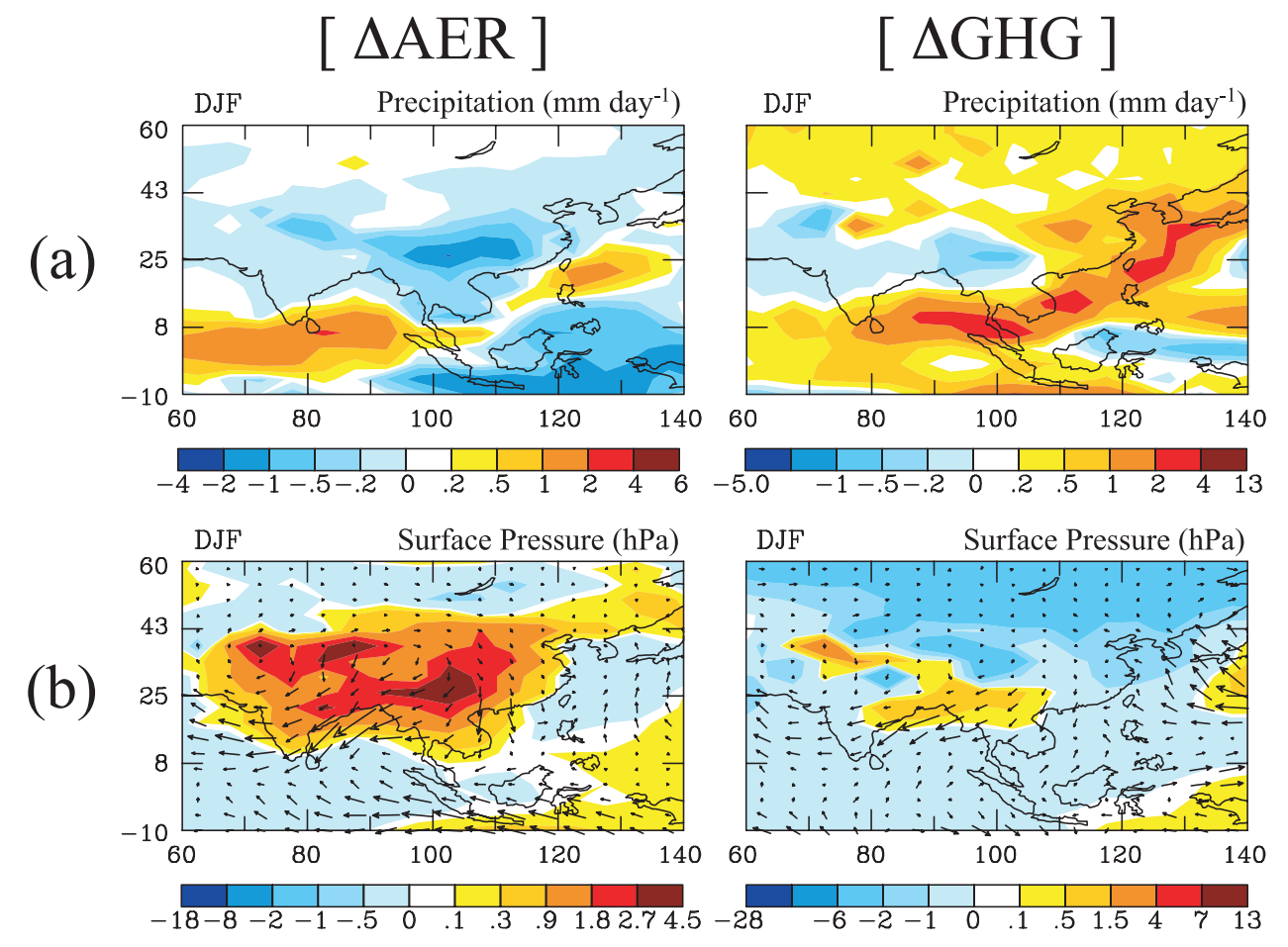

Figure 14. Predicted change over East and South Asia in DJF (a) in precipitation ( $\mathrm{mm} \mathrm{day}^{-1}$ ) and (b) in sea level pressure (color shading, $\mathrm{hPa}$ ) and surface wind field (vector, $\mathrm{m} \mathrm{s}^{-1}$ ). Note that the color scale differs between $\triangle \mathrm{AER}$ and $\triangle \mathrm{GHG}$. 
Table 5. Summary and Comparison of Patterns of Equilibrium Climate Response to Changes of Aerosol Direct Forcing and GHG Forcing From Present Day to Year 2100 Predicted in This Study

\begin{tabular}{|c|c|c|}
\hline & $\triangle \mathrm{AER}$ & $\Delta \mathrm{GHG}$ \\
\hline Surface Temperature & $\begin{array}{l}\text { Cooling in high aerosol burden regions; warming } \\
\text { in northern high latitudes; small change in } \mathrm{SH}\end{array}$ & $\begin{array}{l}\text { Warming globally with polar amplification } \\
\qquad(\mathrm{NH}>\mathrm{SH})\end{array}$ \\
\hline $\begin{array}{l}\text { Interhemispheric Temperature } \\
\text { Gradient }\end{array}$ & $\begin{array}{l}\text { Significant compared to the slight global mean } \\
\text { temperature increase }\end{array}$ & $\begin{array}{l}\text { Not as significant compared to the large } \\
\text { global mean warming }\end{array}$ \\
\hline $\begin{array}{l}\text { Tropospheric Temperature and } \\
\text { Relative Water Vapor Change }\end{array}$ & Max. increase in NH high-latitude midtroposphere & $\begin{array}{l}\text { Max. increase in Tropical upper troposphere } \\
\text { and northern high-latitude lower troposphere }\end{array}$ \\
\hline Hadley Circulation & Strengthened in DJF and weakened in JJA & $\begin{array}{l}\text { Weakened (especially in DJF) except in the } \\
\text { ascending branch in the convection zone }\end{array}$ \\
\hline $\begin{array}{l}\text { Excess Precipitation and } \\
\text { MC Cloud }\end{array}$ & $\begin{array}{l}\text { Changes confined to the Tropics (increase in north, } \\
\text { decrease south of the Equator) }\end{array}$ & $\begin{array}{l}\text { Increase peaks in both the Tropics and middle } \\
\text { to high latitudes }\end{array}$ \\
\hline Surface Energy Balance & $\begin{array}{l}\text { Reduction of SW flux in NH balanced by increase } \\
\text { of downward SH flux and small decrease of upward } \\
\text { LH flux }\end{array}$ & $\begin{array}{c}\text { Increase of downward LW flux, downward } \\
\text { SH flux, and SW flux in high latitudes } \\
\text { balanced by increase of upward LH flux }\end{array}$ \\
\hline
\end{tabular}

2001]. GHG induce large regional mean surface temperature increases in DJF over East Asia $(5.8 \mathrm{~K})$ and South Asia $(5.1 \mathrm{~K})$, which leads to an increase in regional mean evaporation of 0.4 and $0.2 \mathrm{~mm}$ day $^{-1}$, respectively. The additional moisture from increasing evaporation causes precipitation increase of $0.4 \mathrm{~mm}_{\text {day }}{ }^{-1}$ in East Asia, whereas the DJF mean precipitation change in India in GHG perturbation is small and statistically insignificant. Figure 14a also shows a strong precipitation increase is predicted from subtropical to the midlatitude western Pacific, likely associated with the equatorward shift of the storm track due to the decrease of the latitudinal temperature gradient between middle and high latitudes.

\section{Summary and Conclusions}

[35] The direct climatic effect of projected changes in anthropogenic aerosols (sulfates, nitrates, OC, and $\mathrm{BC}$ ), tropospheric ozone, and long-lived greenhouse gases between present day and year 2100 is investigated by means of four equilibrium climate simulations. Concentrations of anthropogenic aerosols and tropospheric ozone for years 2000 and 2100 are derived by the online GCM simulation of coupled tropospheric chemistry and aerosols. Emissions of aerosol/aerosol precursors, ozone precursors, as well as the mixing ratios of GHG are based on the IPCC SRES A2 scenario. Aerosol indirect effects are not considered; therefore, the current study does not present an entire picture of aerosol effects on climate. The resulting global annual mean direct radiative forcing for aerosol, ozone, and GHG from year 2000 to 2100 are predicted to be $+0.18,+0.65$, and $+6.54 \mathrm{~W} \mathrm{~m}^{-2}$ at the tropopause, and $-3.02,+0.02$, and $+1.37 \mathrm{~W} \mathrm{~m}^{-2}$ at the surface, respectively.

[36] The predicted climate effect of changing anthropogenic aerosol direct forcing from present day to year 2100 , $\triangle \mathrm{AER}$, shows a small increase in global annual mean surface temperature of $0.14 \mathrm{~K}$ with substantial regional cooling of around 1-2 K in East Asia, South Asia, West Europe, and the Sahel, especially in the months DJF. The perturbation in anthropogenic aerosols is also predicted to change the inter-hemispheric temperature gradient, which leads to a year-round anomalous vertical circulation over the Tropics and slight changes in the global zonal wind field. The predicted change in the global hydrological cycle in $\triangle \mathrm{AER}$, following the change in circulation and water vapor concentration, is only pronounced in the Tropical region: the enhancement/reduction in water vapor concentration and convective precipitation/cloud in the northern/southern equatorial regional. Change in both aerosol and tropospheric ozone from present day to 2100 is predicted to lead to a global mean temperature increase of $0.48 \mathrm{~K}$. Corresponding changes in latitudinal temperature gradient, global circulation, water vapor, and precipitation are similar to that predicted in the aerosol-only perturbation but of a greater magnitude. The predicted GHG climate effect in the present study generally agrees with previous GCM simulations complied in IPCC [2001], with an increase in global annual mean surface temperature by $5.31 \mathrm{~K}$, an amplified warming in the $\mathrm{NH}$ polar region, maximized heating in the tropical upper troposphere, weakening of the Hadley circulation, and precipitation increase in the Tropics and middle to high latitudes. The latitudinal distribution of changes in tropospheric temperature, circulation, water vapor, and precipitation induced by changing GHG, however, is very different from that induced by anthropogenic aerosol direct forcing; a summary is provided in Table 5 .

[37] Analysis of regional climate change predicted over the East and South Asia in DJF reveals that aerosol direct effect alone ( $\triangle \mathrm{AER})$ can lower the surface $\mathrm{SW}$ flux by as much as $22 \mathrm{~W} \mathrm{~m}^{-2}$. The induced surface cooling predicted with the aerosol-only perturbation ( $\triangle \mathrm{AER})$ can potentially alter the synoptic-scale wind flow and precipitation patterns: East and South Asia is predicted to experience aerosolinduced rainfall suppression in DJF owing to the predicted high pressure anomaly residing over southern China, the Tibetan Plateau, and India, together with an increase in atmospheric stability and decrease in evaporation. On the other hand, regional warming due to the change of GHG $(\triangle \mathrm{GHG})$ is predicted to significantly enhance evaporation over South and East China, and to increase precipitation over East China and subtropical western Pacific.

[38] Acknowledgments. This work was supported by the National Aeronautics and Space Administration Earth Observing System Interdisciplinary Science Program (NASA EOS-IDS). Hong Liao was partially supported by the 100-Talent Project of Chinese Academy of Sciences. The authors thank Tapio Schneider for helpful comments.

\section{References}

Bhaskaran, B., and J. F. B. Mitchell (1998), Simulated changes in Southeast Asian monsoon precipitation resulting from anthropogenic emissions, Int. J. Climatol., 18(13), 1455-1462.

Boer, G. J., G. Flato, M. C. Reader, and D. Ramsden (2000), A transient climate change simulation with greenhouse gas and aerosol forcing: Ex- 
perimental design and comparison with the instrumental record for the twentieth century, Clim. Dyn., 16(6), 405-425.

Chung, S. H., and J. H. Seinfeld (2005), Climate response of direct radiative forcing of anthropogenic black carbon, J. Geophys. Res., 110(D11), D11102, doi:10.1029/2004JD005441.

Chung, C. E., V. Ramanathan, and J. T. Kiehl (2002), Effects of the south Asian absorbing haze on the northeast monsoon and surface-air heat exchange, J. Clim., 15(17), 2462-2476.

Dai, A. G., T. M. L. Wigley, B. A. Boville, J. T. Kiehl, and L. E. Buja (2001), Climates of the twentieth and twenty-first centuries simulated by the NCAR climate system model, J. Clim., 14(4), 485-519.

d'Almeida, G. A., P. Koepke, and E. P. Shettle (1991), Atmospheric Aerosol: Global Climatology and Radiative Characteristics, edited by A. Deepak, Hampton, Va.

Grenfell, J. L., D. T. Shindell, D. Koch, and D. Rind (2001), Chemistryclimate interactions in the Goddard Institute for Space Studies general circulation model: 2 . New insights into modeling the pre-industrial atmosphere, J. Geophys. Res., 106(D24), 33,435-33,451.

Hansen, J., A. Lacis, G. Russel, P. Stone, I. Fung, R. Ruedy, and J. Lerner (1984), Climate sensitivity: Analysis of feedback mechanisms, in Climate Processes and Climate Sensitivity, Geophys. Monogr. Ser., edited by J. Hansen and T. Takahashi, pp. 130-163, AGU, Washington, D. C.

Hansen, J., M. Sato, and R. Ruedy (1997), Radiative forcing and climate response, J. Geophys. Res., 102(D6), 6831-6864.

Held, I. M., and B. J. Soden (2006), Robust responses of the hydrological cycle to global warming, J. Clim., 19(21), 5686-5699.

Intergovernmental Panel on Climate Change (IPCC) (1995), Climate Change 1995, edited by J. T. Houghton et al., Cambridge Univ. Press, New York.

Intergovernmental Panel on Climate Change (IPCC) (2001), Climate Change 2001, edited by J. T. Houghton et al., Cambridge Univ. Press, New York.

Jacobson, M. Z. (2004), Climate response of fossil fuel and biofuel soot, accounting for soot's feedback to snow and sea ice albedo and emissivity, J. Geophys. Res., 109, D21201, doi:10.1029/2004JD004945.

Kiehl, J. T., C. A. Shields, J. J. Hack, and W. D. Collins (2006), The climate sensitivity of the Community Climate System Model: CCM3, J. Clim., 19(11), 2584-2596.

Knutson, T. R., and S. Manabe (1995), Time-mean response over the Tropical Pacific to increased $\mathrm{CO}_{2}$ in a coupled ocean-atmosphere model, J. Clim., 8(9), 2189-2199.

Liao, H., and J. H. Seinfeld (2005), Global impacts of gas-phase chemistryaerosol interactions on direct radiative forcing by anthropogenic aerosols and ozone, J. Geophys. Res., 110, D18208, doi:10.1029/2005JD005907.

Liao, H., P. J. Adams, S. H. Chung, J. H. Seinfeld, L. J. Mickley, and D. J. Jacob (2003), Interactions between tropospheric chemistry and aerosols in a unified general circulation model, J. Geophys. Res., 108(D1), 4001, doi:10.1029/2001JD001260.

Liao, H., J. H. Seinfeld, P. J. Adams, and L. J. Mickley (2004), Global radiative forcing of coupled tropospheric ozone and aerosols in a unified general circulation model, J. Geophys. Res., 109, D16207, doi:10.1029/ 2003JD004456.

Liao, H., W.-T. Chen, and J. H. Seinfeld (2006), Role of climate change in global predictions of future tropospheric ozone and aerosols, J. Geophys. Res., 111, D12304, doi:10.1029/2005JD006852.

Liepert, B. G., J. Feichter, U. Lohmann, and E. Roeckner (2004), Can aerosols spin down the water cycle in a warmer and moister world? Geophys. Res. Lett., 31, L06207, doi:10.1029/2003GL019060.

Manabe, S., and R. T. Wetherald (1975), Effects of doubling $\mathrm{CO}_{2}$ concentration on climate of a general circulation model, J. Atmos. Sci., 32(1), $3-15$.

Menon, S. (2004), Current uncertainties in assessing aerosol effects on climate, Annu. Rev. Environ. Res., 29(1), 1-30.

Menon, S., J. Hansen, L. Nazarenko, and Y. F. Luo (2002), Climate effects of black carbon aerosols in China and India, Science, 297(5590), 22502253.

Mickley, L. J., D. J. Jacob, B. D. Field, and D. Rind (2004), Climate response to the increase in tropospheric ozone since preindustrial times: A comparison between ozone and equivalent $\mathrm{CO}_{2}$ forcings, J. Geophys. Res., 109, D05106, doi:10.1029/2003JD003653.

Mitas, C. M., and A. Clement (2006), Recent behavior of the Hadley cell and tropical thermodynamics in climate models and reanalyses, Geophys. Res. Lett., 33, L01810, doi:10.1029/2005GL024406.
Nakićenović, N., et al. (2000), Emissions Scenarios. A Special Report of Working Group III of the Intergovernmental Panel on Climate Change, edited 599 pp., Cambridge Univ. Press, New York.

Ramanathan, V., C. Chung, D. Kim, T. Bettge, L. Buja, J. T. Kiehl, W. M. Washington, Q. Fu, D. R. Sikka, and M. Wild (2005), Atmospheric brown clouds: Impacts on South Asian climate and hydrological cycle, Proc. Natl. Acad. Sci., 102(15), 5326-5333.

Ramaswamy, V., and M. M. Bowen (1994), Effect of changes in radiatively active species upon the lower stratospheric temperatures, J. Geophys. Res., 99(D9), 18,909-18,921.

Rind, D., and J. Lerner (1996), Use of on-line tracers as a diagnostic tool in general circulation model development, 1 . Horizontal and vertical transport in the troposphere, J. Geophys. Res., 101(D7), 12,667-12,683.

Rind, D., J. Lerner, K. Shah, and R. Suozzo (1999), Use of on-line tracers as a diagnostic tool in general circulation model development, 2. Transport between the troposphere and stratosphere, J. Geophys. Res., 104(D8), 9151-9167.

Rind, D., J. Lerner, and C. McLinden (2001), Changes of tracer distributions in the doubled $\mathrm{CO}_{2}$ climate, J. Geophys. Res., 106(D22), 28,06128,079 .

Roeckner, E., P. Stier, J. Feichter, S. Kloster, M. Esch, and I. Fischer-Bruns (2006), Impact of carbonaceous aerosol emissions on regional climate change, Clim. Dyn., 27(6), 553-571, doi:10.1007/s00382-006-0147-3.

Russell, G. L., J. R. Miller, and L. C. Tsang (1985), Seasonal oceanic heat transports computed from an atmospheric model, Dyn. Atmos. Oceans, 9(3), 253-271.

Schulz, M., et al. (2006), Radiative forcing by aerosols as derived from the AeroCom present-day and pre-industrial simulations, Atmos. Chem. Phys., 6, 5225-5246.

Shindell, D. T., J. L. Grenfell, D. Rind, V. Grewe, and C. Price (2001), Chemistry-climate interactions in the Goddard Institute for Space Studies general circulation model: 1 . Tropospheric chemistry model description and evaluation, J. Geophys. Res., 106(D8), 8047-8075.

Shindell, D., G. Faluvegi, A. Lacis, J. Hansen, and R. Ruedy (2006), Role of tropospheric ozone increases in 20th-century climate change, J. Geophys. Res., 111, D08302, doi:10.1029/2005JD006348.

Stier, P., J. Feichter, E. Roeckner, S. Kloster, and M. Esch (2005), The evolution of the global aerosol system in a transient climate simulation from 1860 to 2100, Atmos. Chem. Phys. Disc., (5), 12,775-12,814.

Stuber, N., M. Ponater, and R. Sausen (2001), Is the climate sensitivity to ozone perturbations enhanced by stratospheric water vapor feedback?, Geophys. Res. Lett., 28(15), 2887-2890.

Takemura, T., T. Nozawa, S. Emori, T. Y. Nakajima, and T. Nakajima (2005), Simulation of climate response to aerosol direct and indirect effects with aerosol transport-radiation model, J. Geophys. Res., 110, D02202, doi:10.1029/2004JD005029.

Toon, O. B., J. B. Pollack, and B. N. Khare (1976), Optical-constants of several atmospheric aerosol species - Ammonium-sulfate, aluminumoxide, and sodium-chloride, J. Geophys. Res., 81(33), 5733-5748.

Wang, C. (2004), A modeling study on the climate impacts of black carbon aerosols, J. Geophys. Res., 109, D03106, doi:10.1029/2003JD004084.

Wang, C. (2007), Impact of direct radiative forcing of black carbon aerosols on tropical convective precipitation, Geophys. Res. Lett., 34, L05709, doi:10.1029/2006GL028416.

Watterson, I. G., and M. R. Dix (2003), Simulated changes due to global warming in daily precipitation means and extremes and their interpretation using the gamma distribution, J. Geophys. Res., 108(D13), 4379, doi:10.1029/2002JD002928.

Zwiers, F. W., and H. von Storch (1995), Taking serial-correlation into account in tests of the mean, J. Clim., 8(2), 336-351.

W.-T. Chen, Department of Environmental Science and Engineering, California Institute of Technology, 1200 East California Blvd., Mail code 210-41, Pasadena, CA 91125, USA. (annechen@caltech.edu)

H. Liao, LAPC, Institute of Atmospheric Physics, Chinese Academy of Sciences, Beijing, China. (hongliao@mail.iap.ac.cn)

J. H. Seinfeld, Department of Environmental Science and Engineering and Chemical Engineering, California Institute of Technology, Pasadena, CA 91125, USA. (seinfeld@caltech.edu) 